\title{
Refractory black carbon (rBC) variability in a 47-year West Antarctic snow and firn core
}

\author{
Luciano Marquetto ${ }^{1,2}$, Susan Kaspari ${ }^{1}$, and Jefferson Cardia Simões ${ }^{2,3}$ \\ ${ }^{1}$ Department of Geological Sciences, Central Washington University, Ellensburg, Washington 98926, USA \\ ${ }^{2}$ Centro Polar e Climático, Universidade Federal do Rio Grande do Sul, Av, Bento Gonçalves 9500, \\ Porto Alegre, Rio Grande do Sul, CEP, 91509-900, Brazil \\ ${ }^{3}$ Climate Change Institute, University of Maine, Orono, Maine 04469-5790, USA
}

Correspondence: Luciano Marquetto (luciano.marquetto@gmail.com)

Received: 3 September 2019 - Discussion started: 6 November 2019

Revised: 10 March 2020 - Accepted: 9 April 2020 - Published: 12 May 2020

\begin{abstract}
Black carbon (BC) is an important climate-forcing agent that affects snow albedo. In this work, we present a record of refractory black carbon (rBC) variability, measured from a $20 \mathrm{~m}$ deep snow and firn core drilled in West Antarctica $\left(79^{\circ} 55^{\prime} 34.6^{\prime \prime} \mathrm{S}, 94^{\circ} 21^{\prime} 13.3^{\prime \prime} \mathrm{W}, 2122 \mathrm{~m}\right.$ above sea level) during the 2014-2015 austral summer. This is the highest elevation $\mathrm{rBC}$ record from West Antarctica. The core was analyzed using the Single Particle Soot Photometer (SP2) coupled to a CETAC Marin-5 nebulizer. Results show a welldefined seasonality with geometric mean concentrations of $0.015 \mu \mathrm{g} \mathrm{L}^{-1}$ for the wet season (austral summer-fall) and $0.057 \mu \mathrm{g} \mathrm{L}^{-1}$ for the dry season (austral winter-spring). The core was dated to 47 years (1968-2015) using rBC seasonality as the main parameter, along with sodium $(\mathrm{Na})$, sulfur $(\mathrm{S})$ and strontium (Sr) variations. The annual rBC concentration geometric mean was $0.03 \mu \mathrm{g} \mathrm{L}-1$, the lowest of all $\mathrm{rBC}$ cores in Antarctica referenced in this work, while the annual $\mathrm{rBC}$ flux was $6.25 \mu \mathrm{g} \mathrm{m}^{-2} \mathrm{a}^{-1}$, the lowest flux in West Antarctica rBC records. No long-term trend was observed. Snow albedo reductions at the site due to $\mathrm{BC}$ were simulated using SNICAR online and found to be insignificant $(-0.48 \%)$ compared to clean snow. Fire spot inventory and $\mathrm{BC}$ emission estimates from the Southern Hemisphere suggest Australia and Southern Hemisphere South America as the most probable emission sources of BC to the drilling site, whereas HYSPLIT model particle transport simulations from 1968 to 2015 support Australia and New Zealand as rBC sources, with limited contributions from South America. Spectral analysis (REDFIT method) of the BC record showed cycles related to the Antarctic Oscillation (AAO) and
\end{abstract}

to El Niño-Southern Oscillation (ENSO), but cycles in common with the Amundsen Sea Low (ASL) were not detected. Correlation of $\mathrm{rBC}$ records in Antarctica with snow accumulation, elevation and distance to the sea suggests $\mathrm{rBC}$ transport to East Antarctica is different from transport to West Antarctica.

\section{Introduction}

Black carbon (BC) is a carbonaceous aerosol formed during incomplete combustion of biomass and fossil fuels, characterized by strong absorption of visible light and resistance to chemical transformation (Petzold et al., 2013), and it plays an important role in the climatic system by being able to alter the planetary albedo (McConnell et al., 2007; Ni et al., 2014).

BC-containing aerosols are the species most commonly identified as being short-lived climate forcers, along with methane and ozone (AMAP, 2015). BC particles stay in the atmosphere for just 1 week to $10 \mathrm{~d}$ (Bond et al., 2013; Ni et al., 2014), but during that time they change the direct radiative forcing at the top of the atmosphere by absorbing and scattering sunlight, with high spatial and temporal variability on regional scales (Bond et al., 2013). In some parts of the globe, the impact of $\mathrm{BC}$ on the climate can be even higher than greenhouse gases (Bice et al., 2009). Globally $\mathrm{BC}$ is estimated to be second only to $\mathrm{CO}_{2}$ in its contribution to climate forcing, with $+1.1 \mathrm{~W} \mathrm{~m}^{-2}$ for the indus- 
trial era (1750-2005) (Bond et al., 2013; Ramanathan and Carmichael, 2008)

Increases in $\mathrm{BC}$ concentrations in the cryosphere since the industrial revolution have been observed, with most studies focusing on the Arctic, the Himalayas and European glaciers as these ice caps are close to large urban centers and consequently are influenced by these. Antarctica is a pristine environment far from the rest of the world, but $\mathrm{BC}$ can still be found in its atmosphere, snow and ice, as shown by early studies (Chýlek et al., 1987, 1992; Warren and Clarke, 1990). Although there are local emissions of BC due to scientific and touristic activities (Casey et al., 2017; Stohl and Sodemann, 2010), Antarctic ice also records Southern Hemisphere (SH) emissions and long-range transport of $\mathrm{BC}$ from low and midlatitudes (Bisiaux et al., 2012a, b; Pasteris et al., 2014), with BC concentrations in Antarctica being linked to biomass burning from South America, Africa and Australia (Arienzo et al., 2017; Koch et al., 2007; Stohl and Sodemann, 2010). Even tropical latitude emissions have a measurable influence on the continent (Fiebig et al., 2009).

Although there are several records of SH paleo-biomass burning, there are only a few publications on $\mathrm{BC}$ variability in ice cores from Antarctica. Some of those are focused on centennial-millennial timescales (Arienzo et al., 2017; Chýlek et al., 1992) and others on annual to decadal scales (Bisiaux et al., 2012a, b; Pasteris et al., 2014). More ice core records are needed to understand the spatial variability of $\mathrm{BC}$ transport and deposition to Antarctica, as well as to improve general circulation models (Bisiaux et al., 2012b). In this work we present a new West Antarctic high-temporalresolution $\mathrm{rBC}$ snow and firn core record. This record is the highest West Antarctic rBC record produced to date and contributes to the understanding of $\mathrm{BC}$ temporal and spatial variability in Antarctica.

\section{Site description and field campaign}

The core (TT07) was drilled in the 2014-2015 austral summer on the Pine Island Glacier (West Antarctica) at $79^{\circ} 55^{\prime} 34.6^{\prime \prime} \mathrm{S}, 94^{\circ} 21^{\prime} 13.3^{\prime \prime} \mathrm{W}$ (elevation $2122 \mathrm{~m}$ above sea level - a.s.l.), near the Mount Johns nunatak (located $70 \mathrm{~km}$ NE of the drilling site) (Fig. 1) and close to the InstitutePine Island ice divide. The drilling site was chosen due to its relatively high accumulation rate, which ensures seasonally preserved stratigraphic resolution (Schwanck et al., 2016b; Thoen et al., 2018), and due to the region's interesting pattern of atmospheric circulation, originating from the confluence of air masses from the Weddell, Amundsen and Bellingshausen seas (Parish and Bromwich, 2007; Thoen et al., 2018).

The West Antarctic Ice Sheet (WAIS) has a lower elevation and lower coastal slopes than the East Antarctic Ice Sheet (EAIS), which facilitates the intrusion of moisturerich cyclones to the interior of the continent and the trans-

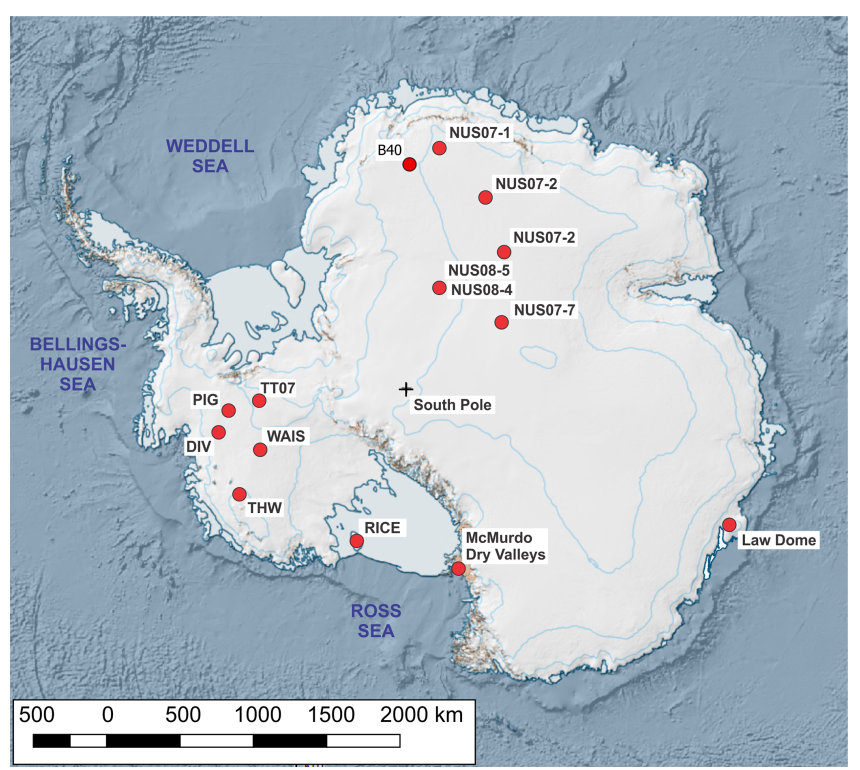

Figure 1. Drilling location for the snow and firn core analyzed in this work (TT07) and other points of interest mentioned in the text. Base map from the Quantarctica project (Matsuoka et al., 2018).

port of aerosols inland (Neff and Bertler, 2015; Nicolas and Bromwich, 2011). Katabatic winds are not as strong in the drilling site region as they are in most of West Antarctica, due to the higher site elevation compared to the surroundings (Parish and Bromwich, 2007). Seasonal differences in atmospheric transport have been reported for the TT07 drilling site, with particle trajectories during the austral summer being slow moving and more locally influenced, while, during the winter, air trajectories are influenced by oceanic air masses due to strong westerlies. The majority of air masses arrive from the Amundsen Sea and, secondarily, from across the Antarctic Peninsula and Weddell Sea (Schwanck et al., 2017). These are also the preferred pathway for dust particles (Neff and Bertler, 2015).

We used a Mark III auger (Kovacs Enterprises, Inc.) coupled with an electrical drive powered by a generator (kept downwind at a minimum of $30 \mathrm{~m}$ away) to retrieve the core. The Mark III auger recovers cylinders of $7.25 \mathrm{~cm}$ diameter and up to $1 \mathrm{~m}$ long. All sections of the core were weighed in the field, packed in polyethylene bags and then stored in high-density styrofoam boxes. These boxes were sent by air to Punta Arenas (Chile), then to a deposit in Bangor (ME, US) for storing and finally to the Central Washington University Ice Core Laboratory (Ellensburg, WA), where they were kept at $-1{ }^{\circ} \mathrm{C}$ in a clean cold room until subsampling and analysis. 


\section{Methods}

\section{1 rBC analytical method}

We used an extended-range Single Particle Soot Photometer (SP2, Droplet Measurement Technologies, Boulder, CO, USA) at the Department of Geological Sciences, Central Washington University (CWU - WA, USA) to analyze our samples. The particle size range detected by the SP2 at CWU is $80-2000 \mathrm{~nm}$ mass-equivalent diameter for the incandescent signal, assuming a void-free BC density of $1.8 \mathrm{~g} \mathrm{~cm}^{-3}$ (Moteki and Kondo, 2010).

The SP2 measures the number and size of $\mathrm{rBC}$ particles using laser-induced incandescence and was used in a variety of studies for BC in snow and ice (Bisiaux et al., 2012a, b; Casey et al., 2017; Kaspari et al., 2014, 2015, 2011; McConnell et al., 2007; Osmont et al., 2018, 2019). In this work we use the recommended terminology by Petzold et al. (2013) and present results from the SP2 as refractory black carbon (rBC).

As the SP2 was initially designed to analyze $\mathrm{rBC}$ from the atmosphere (dry aerosol), a necessary step to run liquid samples is their nebulization before being coupled to the sample inlet of the SP2. For this, we used a CETAC Marin-5, described in detail by Mori et al. (2016). The authors found a good nebulizing efficiency of $50.0 \pm 4.4 \%$ and no size dependency in the diameter range of 200-2000 nm. Katich et al. (2017) managed to obtain nebulization efficiencies near $100 \%$ with their equipment setup. We calculated the CWU Marin-5 nebulization efficiency to be $68.3 \pm 5.9 \%(1 \sigma)$ based on the external calibration carried out every working day using Aquadag standards (Marquetto et al., 2020). We found a decrease in nebulization efficiency during the laboratory work period $(-0.31 \%$ per working day or $-13.3 \%$ over the 43 working days), but we assume the nebulization efficiency to remain stable between the measurement of the standard and the samples measured for the day, following Katich et al. (2017). We attribute this decrease to the Marin-5 but do not see any apparent cause. Liquid pump flow rates were kept constant at $0.14 \pm 0.02 \mathrm{~mL} \mathrm{~min}^{-1}$ during analysis.

For details of the CWU SP2 internal and external calibration, refer to Marquetto et al. (2020).

\subsection{Laboratory and vial cleaning}

Regular intensive cleaning was carried out inside the cold room for all surfaces, parts and equipment in contact with the core using ethanol and laboratory-grade paper tissues. Tyvek suits (DuPont, Wilmington, DE, USA) and sterile plastic gloves were used at all times in the cold room during the core processing.

Vials used to store the samples $(50 \mathrm{~mL}$ polypropylene vials) were soaked in Milli-Q water for $24 \mathrm{~h}$ and rinsed three times. This process was repeated two more times, in a total of $3 \mathrm{~d}$ with the samples soaked in Milli-Q water and rinsed a total of nine times. The vials were left to dry, covered from direct contact, in the laboratory.

\subsection{Sample preparation}

The sample preparation process consists of removing the outer layers of the core, as these are prone to contamination during drilling, handling and transport of the core (Tao et al., 2001). In the cold room, we partitioned the 21 sections of the core longitudinally, using a bandsaw with a meat-grade, stainless-steel blade. For every cutting session, a Milli-Q (MQ) ice stick, previously prepared, was cut at the beginning, to guarantee a clean blade for the snow and firn core. After cutting the core with the bandsaw, we hand-scraped the resulting snow and firn sticks with a ceramic knife in a laminar flow hood (still in the cold room) and cut them in 2 $2.5 \mathrm{~cm}$ samples with the same knife (resulting in $\sim 40 \mathrm{sam}-$ ples per section). We stored the samples in the pre-cleaned $50 \mathrm{~mL}$ polypropylene vials and kept them frozen until analysis. Samples were melted at room temperature or in a tepid bath not exceeding $25^{\circ} \mathrm{C}$, sonicated for $15 \mathrm{~min}$ and then analyzed (in less than $1 \mathrm{~h}$ after melting). The resulting $\mathrm{rBC}$ concentrations using this subsampling method were compared to subsampling using a continuous melter system for the first $8 \mathrm{~m}$ of the core, and results for both methods were statistically the same (Marquetto et al., 2020).

From all steps of the sample preparation, the bandsaw cutting in the cold room proved to be the most prone to contaminating samples. An intensive decontamination process was carried out for a month, before we could start working with the core itself. In order to reach acceptable background levels for this step (around $0.02 \mu \mathrm{g} \mathrm{L}^{-1}$ ), we replaced and modified some components of the bandsaw. We replaced the rubber tires for urethane ones; the carbon blade for a meat-grade, stainless-steel blade; and the original plastic blade guides for ceramic ones, and we manufactured an acrylic blade guard, as the original plastic guard was chipping. Before using the new blade, we burned it using a blowtorch and MAP/Pro gas (propylene with $<0.5 \%$ propane) to remove any residues or oils present; then we cleaned it with ethanol. For detachable parts, a detergent was used, followed by ethanol and MQ water. For parts inside the cold room, ethanol was used. We also prepared ice sticks of MQ water to cut in the bandsaw and help clean the blade.

\subsection{Whole-system setup}

The setup for the system in use at CWU is as it follows. The melted sample is dispensed to the Marin-5 nebulizer by a Reglo Digital peristaltic pump (ISMATEC, Wertheim, Germany) at $0.14 \pm 0.02 \mathrm{~mL} \mathrm{~min}^{-1}$ and monitored by a TruFlo sample monitor (Glass Expansion, Port Melbourne, Australia). The Marin-5 nebulizer receives standard laboratory air at $1000 \mathrm{sccm}\left(1000 \mathrm{~L} \mathrm{~min}^{-1}\right)$, regulated by an Alicat flow controller (Alicat Scientific, Tucson, AZ, USA) connected 
to a Drierite gas purifier, which removes any moisture or particulates from the air. The nebulizer heating and cooling temperatures are set to 110 and $5{ }^{\circ} \mathrm{C}$, respectively, following Mori et al. (2016). We used Tygon LFL tubing i.d. $1.02 \mathrm{~mm}$ (Saint-Gobain Performance Plastics, France) for sample-tonebulizer connection. The SP2 flow is maintained at 120 volumetric $\mathrm{cm}^{3} \mathrm{~min}^{-1}$ (vccm). YAG laser power for this project stayed constant above $5.0 \mathrm{~V}$.

Samples were analyzed for $5 \mathrm{~min}$ each. Procedural blanks (MQ water) were run at the beginning and end of every working day and also every 15-20 samples. Background levels were kept at $0-0.5$ particles $\mathrm{cm}^{-3}$ (translating to less than $0.01 \mu \mathrm{g} \mathrm{L}-1$ rBC concentration), and a $5 \%$ HNO3 solution was used for cleaning the tubing and nebulizer when needed. For the SP2 to go back to background levels, only MQ water was used. Peristaltic pump tubing replacement was necessary only once during the process. The limit of detection (LOD) of the method was estimated to be $1.61 \times 10-3 \mu \mathrm{g} \mathrm{L}^{-1}$ based on procedural blanks measured to characterize the instrument detection limit (mean $+3 \sigma, n=30$ ).

Data processing was performed with the SP2 Toolkit 4.200 developed by the Laboratory of Atmospheric Chemistry at the Paul Scherrer Institute (PSI) and was used on the scientific data analysis software IGOR Pro version 6.3.

\subsection{Fire spots and $\mathrm{BC}$ emission database}

To help define the dating of the core and to investigate potential emission source regions, we compared our results with two different datasets: $\mathrm{BC}$ emission estimates from the Global Fire Emission Database version 4s (GFED4s - van Der Werf et al., 2017) for the SH (SH South America, SH Africa, Australia and Equatorial Asia) and the Australian and Brazilian satellite programs, which count the fire spots (number of active fires) in Oceania and South America, respectively.

The GFED4s (https://www.globalfiredata.org/data.html, last access: 13 June 2019) is based on the Carnegie Ames Stanford Approach biogeochemical model (Giglio et al., 2013) and has several improvements compared with the earlier version, including burned area and emissions from small fires as these could be substantial at a global scale (Randerson et al., 2012). BC emission estimates are given in $10^{9} \mathrm{~g}$ and separated by region of the globe with a spatial resolution of $0.25^{\circ}$ latitude by $0.25^{\circ}$ longitude. For the Southern Hemisphere, four regions are identified: Southern Hemisphere Africa (SHAF), Southern Hemisphere South America (SHSA), Australia and New Zealand (AUS), and equatorial Asia (EQAS).

Sentinel Hotspots (https://www.ga.gov.au/ scientific-topics/earth-obs/case-studies/mapping-bushfires, last access: 13 June 2019) and the Programa Queimadas (http://www.inpe.br/queimadas/, last access: 13 June 2019) are fire monitoring programs run by the government of Australia (Geoscience Australia) and Brazil (Instituto
Nacional de Pesquisas Espaciais - INPE), respectively. Both programs use Moderate Resolution Imaging Spectroradiometer (MODIS), Advanced Very High-Resolution Radiometer (AVHRR) and Visible Infrared Radiometer Suite (VIIRS) sensors to detect areas of elevated infrared radiation. The Sentinel Hotspots holds data from 2002 to present, while Programa Queimadas has a record of fire spots since 1998. The parameter "fire spot" used in both Australian and Brazilian fire monitoring programs does not translate directly to the dimension and intensity of the biomass burning events, but it holds a correlation with burned area (Andela et al., 2017) and thus can be used to help date the core and investigate potential emission sources.

\subsection{Core dating}

Antarctic ice core $\mathrm{rBC}$ records from other sites show a well-defined seasonality, with peak concentrations in austral winter-spring (dry season) due to increased biomass burning activity in the SH during this time of the year (Bisiaux et al., 2012b; Pasteris et al., 2014; Sand et al., 2017; Winstrup et al., 2019). Sodium (Na) and strontium (Sr) also peak in the austral dry season (during winter) due to intense atmospheric circulation and transport (Legrand and Mayewski, 1997; Schwanck et al., 2017). Increased marine biogenic activity reflects an increase in sulfur (S) in late austral summer (Schwanck et al., 2017; Sigl et al., 2016). Also, the maxima in the ratio of non-sea-salt sulfur to sodium $(\mathrm{nssS} / \mathrm{Na})$ is a robust seasonal indicator and peaks around the New Year (Arienzo et al., 2017). This parameter helps in the identification of the annual layers more than the $\mathrm{Na}$ and $\mathrm{S}$ records alone. Non-sea-salt sulfur was calculated using Eqs. (3) to (6) from Schwanck et al. (2017) and references therein.

The core was dated by multiparameter manual layer counting primarily driven by $\mathrm{rBC}$ seasonal variability, as this is a reliable parameter for dating in Antarctica (Sigl et al., 2016; Winstrup et al., 2019), and a well-defined seasonality has already been observed for Pine Island Glacier (Pasteris et al., 2014). We used S, Sr, Na and nssS / Na records from a core drilled $1 \mathrm{~m}$ away as additional parameters to the main counting. The trace element records goes down only to $\sim 6.5 \mathrm{~m}$, so below $6.5 \mathrm{~m}$ the ice core is dated using the $\mathrm{rBC}$ record. The trace elements were analyzed by the Climate Change Institute (CCI) Thermo Scientific ELEMENT 2 inductively coupled plasma sector field mass spectrometer (ICP-SFMS) coupled to an ESI model SC-4 autosampler; working conditions and measurement parameters are described in Schwanck et al. (2016b, 2017).

We considered the New Year to match the end of what we define as the austral dry season, as this is a reliable tie point in the record due to the abrupt drop in $\mathrm{rBC}$ concentrations. Previous studies have demonstrated that $\mathrm{rBC}$ deposition occurs in winter-spring, mostly September to December. For example, Arienzo et al. (2017) observed rBC concentrations to peak in September in the WAIS Divide ice core; Winstrup 
et al. (2019) used annual variations in $\mathrm{rBC}$ as the most reliable annual tracer for the Roosevelt Island Climate Evolution (RICE) ice core, stating that $\mathrm{rBC}$ tends to peak earlier in the year than 1 January. Pasteris et al. (2014) also corroborates rBC to peak in October and drop after for the Pine Island and Thwaites glaciers, with the lowest values from February to June. Bisiaux et al. (2012b) state that subannual rBC concentrations are highly seasonal in the WAIS Divide ice core for the period spanning 1850-2000 - low austral wet season and high austral dry season concentrations - and presented annual picks in the drop in $\mathrm{rBC}$ concentrations, as in this work. This is also consistent with the $\mathrm{BC}$ emission estimates from GFED4s and the fire spot databases from Australia and South America.

\subsection{Snow accumulation, $r B C$ concentrations and fluxes}

To account for imperfections in the core geometry (and consequently imprecise density measurements), we averaged the core's density profile with the density profile from Schwanck et al. (2016b) for a $45 \mathrm{~m}$ deep core drilled in the same region of West Antarctica, $850 \mathrm{~m}$ away from TT07. We then fitted a quadratic trend line in the average curve and used this trend line instead of the field measurements to calculate the annual snow accumulation, water equivalent (w.e.) and $\mathrm{rBC}$ fluxes. $\mathrm{rBC}$ fluxes were calculated by multiplying annual $\mathrm{rBC}$ means by annual snow accumulation.

We consider that the frequency distributions of the core rBC concentrations are lognormal, and so we present geometric means and geometric standard deviations as these are more appropriate than arithmetic calculations (Bisiaux et al., 2012a; Limpert et al., 2001). The geometric standard deviation is the multiplicative standard deviation $\left(\sigma^{*}\right)$, so the $68.3 \%$ interval of confidence is calculated as $\sigma \min _{\text {conc }}=$ geometric mean $\times$ geometric standard deviation and $\sigma \max _{\text {conc }}=$ geometric mean/geometric standard deviation (Limpert et al., 2001). Also, correlation analysis was carried out using Mann-Kendall's test; we choose it as opposed to Spearman's test as confidence intervals are more reliable in the former (Kendall and Gibbons, 1990; Newson, 2002).

We present our data as austral summer-fall (wet season: January to June) concentrations and austral winterspring (dry season: July to December) concentrations. Wetdry season concentrations and annual concentration geometric means and standard deviations were calculated in the raw $\mathrm{rBC}$ measurements using the dating carried out to separate years and $\mathrm{rBC}$ concentration variations to pinpoint the changes from dry season to wet season and vice versa. Monthly mean concentrations were calculated by applying a linear interpolation in the raw measurements, resampling the dataset to 12 values per year.

\section{8 rBC impact on snow albedo}

To investigate BC impact on snow albedo, we used the Snow, Ice, and Aerosol Radiation (SNICAR) online model (Flanner et al., 2007). We ran the model using the parameters presented in Table 1 with varying $\mathrm{rBC}$ concentrations. We used the wet and dry season geomeans to analyze variations for both seasons and the highest seasonal geomean found in the core, which occurred in the dry season. As our focus in this paper is BC, we simulated albedo changes considering only the particulate and disregarding any dust or volcanic ash influence. Snow grain size used was based on Gay et al. (2002).

\subsection{Spectral analysis}

In order to investigate periodic oscillations (cycles) in the TT07 core and BC atmospheric transport to the drilling site, we conducted a spectral analysis in the $\mathrm{rBC}$ record using the REDFIT procedure described in detail in Schulz and Mudelsee (2002) in the "PAST - Paleontological Statistics" software version 3.25 . The spectral analysis is motivated by the observation that the most predictable (regular) behavior of a time series is to be periodic (Ghil et al., 2002). The REDFIT method is a more advanced version of the simple Lomb periodogram and can be used for evenly and unevenly sampled data. The model is fit to an AR(1) red noise model, the bandwidth is the spectral resolution given as the width between the $-6 \mathrm{~dB}$ points, and confidence levels of $90 \%, 95 \%$ and $99 \%$ are presented (based on chi2) (Hammer, 2019).

We chose this approach instead of estimation techniques for evenly spaced data (such as the multitaper method) because interpolation in the time domain inevitably causes bias and alters the estimated spectrum of a time series (Schulz and Mudelsee, 2002). This way, we used the rBC raw measurements (not resampled, only dated by year and separated by dry-wet season).

We compared the $\mathrm{rBC}$ spectrum with the El NiñoSouthern Oscillation (ENSO), the Antarctic Oscillation (AAO) and the Amundsen Sea Low (ASL) spectra to observe the possible influence of these in the $\mathrm{rBC}$ variability. While ENSO and AAO are well-known climate drivers, recent studies have shown the ASL has a profound effect on the West Antarctic climate (Hosking et al., 2013, 2016; Turner et al., 2013). We also compared the core records with the GFED4s $\mathrm{BC}$ emission estimates and the satellite fire spot database to look for similarities between the datasets which could suggest $\mathrm{BC}$ emission sources to the drilling site. Table 2 shows the dataset used for the spectral analysis.

\subsection{Particle trajectory simulations}

In order to simulate $\mathrm{rBC}$ particle trajectories from source areas to the TT07 drilling site, we used the Hybrid Single Particle Lagrangian Integrated Trajectory v4 model (HYSPLIT - Draxler and Rolph, 2003; Stein et al., 2015), from 
Table 1. Parameters used to calculate albedo changes in snow for the TT07 site.

\begin{tabular}{ll}
\hline Incident flux & Diffuse \\
\hline Surface spectral distribution & Summit Greenland clear-sky \\
Snowpack effective grain size & $150 \mu \mathrm{m}$ \\
Snowpack thickness & $20 \mathrm{~m}$ \\
Snowpack density & $400 \mathrm{~kg} \mathrm{~m}^{-3}$ \\
Visible albedo of underlying surface & 0.2 \\
Near-IR albedo of underlying surface & 0.4 \\
Uncoated black carbon concentration & Varied; see text \\
Sulfate-coated black carbon concentration & $0 \mathrm{ppb}$ \\
Dust concentration & $0 \mathrm{ppm}$ \\
\hline Volcanic ash concentration & $0 \mathrm{ppm}$ \\
Experimental particle one concentration & $0 \mathrm{ppb}$ \\
MAC scaling factor & 1.0 \\
\hline
\end{tabular}

Table 2. Datasets used for the REDFIT spectral analysis.

\begin{tabular}{|c|c|c|c|c|}
\hline Dataset & Data points & Range & Observation & Source \\
\hline $\mathrm{rBC}$ & 860 & $\begin{array}{l}\text { Jan } 1969 \\
\text { Dec } 2014\end{array}$ & Raw data ${ }^{a}$ & TT07 core \\
\hline $\mathrm{ENSO}^{\mathrm{b}}$ & 576 & $\begin{array}{l}\text { Jan } 1967 \\
\text { Dec } 2014\end{array}$ & Monthly data & Bureau of Meteorology, Australia ${ }^{c}$ \\
\hline $\mathrm{AAO}$ & 432 & $\begin{array}{l}\text { Jan } 1979 \\
\text { Dec } 2014\end{array}$ & Monthly data & NOAA $^{d}$ \\
\hline ASL & 432 & $\begin{array}{l}\text { Jan } 1979 \\
\text { Dec } 2014\end{array}$ & Monthly data & BAS, Hosking et al. (2016) \\
\hline GFED4s & 216 & $\begin{array}{l}\text { Jan } 1997 \\
\text { Dec } 2014\end{array}$ & Monthly data & Global Fire Emission Database \\
\hline Sentinel Hotspots & 150 & $\begin{array}{l}\text { Aug } 2002 \\
\text { Dec } 2014\end{array}$ & Monthly data & Geoscience Australia \\
\hline Programa Queimadas & 200 & $\begin{array}{l}\text { May } 1998 \\
\text { Dec } 2014\end{array}$ & Monthly data & INPE \\
\hline
\end{tabular}

${ }^{a}$ Not resampled, only dated by year and separated by dry-wet season. ${ }^{b}$ Here we use the Southern Oscillation index - SOI as the ENSO indicator. ${ }^{c}$ http://www.bom.gov.au/climate/current/soihtm1.shtml, last access: 15 June 2019.

${ }^{\mathrm{d}}$ https://www.cpc.ncep.noaa.gov/products/precip/CWlink/, last access: 15 June 2019. ${ }^{\mathrm{e}}$ https://legacy.bas.ac.uk/data/absl/, last access: 15 June 2019.

NOAA. HYSPLIT is a complete system for computing simple or complex transport and deposition simulations (Stein et al., 2015) that has been used in Antarctica for several studies (Dixon et al., 2011; Markle et al., 2012; Marquetto et al., 2015; Schwanck et al., 2016a, 2017; Sinclair et al., 2010).

We used global reanalysis data from the National Centers for Environmental Prediction (NCEP) and the National Center for Atmospheric Research (NCAR) - the NCEP/NCAR dataset - and ran $10 \mathrm{~d}(240 \mathrm{~h})$ back trajectories, every $5 \mathrm{~d}$, from 1968 to 2015, at an initial height of $1000 \mathrm{~m}$. We consider $10 \mathrm{~d}$ to be an appropriate simulation time as this is the estimated maximum lifetime of BC in the troposphere (IPCC et al., 2013). An initial height of $1000 \mathrm{~m}$ was used in order to minimize disturbance from the underlying terrain, but still maintaining a link with the surface wind field (Sinclair et al., 2010). To identify main airflow patterns at the TT07 drilling site, the individual trajectories were separated into dry and wet seasons (depending on day and month of each run) and simulations from each season were grouped into five clusters using the HYSPLIT model's cluster analysis algorithm. 


\section{Results and discussion}

\subsection{Dating}

The core was dated to 47 years (1968-2015), and details are presented in Fig. 2. We consider this dating to have \pm 2 years uncertainty. The first uncertain year is located at $6.18 \mathrm{~m}$ (between 2003 and 2002, Fig. 2a), where S and nssS / Na peak, but no full cycle is observed in the $\mathrm{rBC}$ record. We did not consider this to be a year, as $\mathrm{rBC}$ does not present a full cycle. The second uncertain year is located at $18.14 \mathrm{~m}$ (year 1973, Fig. 2b) where there is no clear rBC peak but snow accumulation would be anomalously high if considered to be only 1 year instead of 2 . We consider this to be an annual peak and consequently 2 years, as there is no evidence of higherthan-normal snow accumulation in the region for this period (Kaspari et al., 2004).

\subsection{Core density and annual snow accumulation}

The core density (measured in the field) ranged from 0.38 to $0.60 \mathrm{~g} \mathrm{~cm}^{-3}$. Using the corrected density curve obtained from our field measurements and from Schwanck et al. (2016b), we calculated that the $20.16 \mathrm{~m}$ length core represents 10.37 w.e. m (Fig. 3).

Average annual snow accumulation is $0.21 \pm 0.04$ w.e. $\mathrm{m}$ per year and varies little throughout the record, with an exception of a peak in accumulation of 0.31 w.e. $m$ in 1971. The average accumulation is similar to what Banta et al. (2008) found for the WAIS Divide ice core for the last centuries $\left(0.20 \pm 0.03\right.$ w.e. $\mathrm{m} \mathrm{yr}^{-1}$, elevation $1759 \mathrm{~m}$ a.s.l. $)$ and to the higher altitude cores $(>1700 \mathrm{~m}$ a.s.l.) from Kaspari et al. (2004) ( 0.18 to 0.23 w.e. $\mathrm{m} \mathrm{yr}^{-1}$ ); although the latter work also presents lower altitude cores (1200 to $1600 \mathrm{~m}$ a.s.l.) closer to the drilling site with accumulation rates between 0.32 and 0.42 w.e. $\mathrm{m} \mathrm{yr}^{-1}$.

\section{3 rBC concentrations and fluxes}

In agreement with other studies (Bisiaux et al., 2012a; Pasteris et al., 2014; Sand et al., 2017; Winstrup et al., 2019), we found a well-marked seasonal $\mathrm{rBC}$ cycle along the core, with the same pattern of low summer-fall and high winterspring concentrations (Fig. 4). As we collected our samples in January and the drilling was carried out from the snow surface, our core starts at approximately the $2015 \mathrm{New}$ Year. The core's annual rBC geometric mean concentration was $0.030 \mu \mathrm{g} \mathrm{L}^{-1}$ with a minimum of $0.001 \mu \mathrm{g} \mathrm{L}-1$ and a maximum of $0.080 \mu \mathrm{g} \mathrm{L}{ }^{-1}$. Winter-spring (dry season) concentration geometric mean was $0.057 \mu \mathrm{g} \mathrm{L}^{-1}$, while summer-fall (wet season) concentration geometric mean was $0.001 \mu \mathrm{g} \mathrm{L}{ }^{-1}$. Wet season average concentrations remained constant over time, while dry season average concentrations showed more variation with peak values in 1999 but no apparent trend. The main results from TT07 rBC analysis are summarized in Table 3.
Table 3. Main results from the core rBC analysis. All values in micrograms per liter, except fluxes, which are in micrograms per square meter per year. Geomean is the geometric mean and $1 \sigma^{*}$ is the multiplicative standard deviation, representing $68.3 \%$ of the variability (Bisiaux et al., 2012b; Limpert et al., 2001).

\begin{tabular}{lr}
\hline Total samples & 860 \\
\hline Annual geomean & 0.03 \\
$1 \sigma^{*}$ interval & $0.020-0.041$ \\
Lowest/highest & $0.012 / 0.080$ \\
\hline Dry season geomean & 0.057 \\
$1 \sigma^{*}$ interval & $0.031-0.105$ \\
Lowest/highest & $0.005 / 0.332$ \\
\hline Wet season geomean & 0.015 \\
$1 \sigma^{*}$ interval & $0.009-0.027$ \\
Lowest/highest & $0.001 / 0.053$ \\
\hline rBC flux geomean & 6.25 \\
Lowest/highest & $2.67 / 14.61$ \\
\hline
\end{tabular}

We calculated annual $\mathrm{rBC}$ fluxes to account for potential biases in annual $\mathrm{rBC}$ concentrations due to changes in snow accumulation rates. Concentrations and fluxes follow a similar pattern along the core, as can be observed in Fig. 5. This means that $\mathrm{rBC}$ concentration variability likely reflects variations in $\mathrm{BC}$ emissions, transport and deposition at the site instead of reflecting changes in snow accumulation.

\subsection{Comparison with other $\mathrm{rBC}$ records in Antarctica}

BC has been studied in Antarctic snow since the late 1980s and early 1990s (Chýlek et al., 1987, 1992; Warren and Clarke, 1990). These initial studies used filter-based methods, which could under- or overestimate BC concentrations due to some analytical artifacts (Soto-García et al., 2011; Torres et al., 2014; Wang et al., 2012). Studies using the SP2 started appearing more than 2 decades later, aiming at recent snow rBC concentrations (Casey et al., 2017; Khan et al., 2019), near-surface air (Khan et al., 2018), recent-past ice cores (couple centuries - Bisiaux et al., 2012a, b; Pasteris et al., 2014) and the past millennia (Arienzo et al., 2017). From these, a few $\mathrm{rBC}$ records overlap temporally with the TT07 core presented in this work (Table 4). rBC concentrations are low at all sites $\left(<0.5 \mu \mathrm{g} \mathrm{L}^{-1}\right)$; thus small differences in concentration from one core to another could result in a $2-3$-fold difference in $\mathrm{rBC}$ concentrations.

Pasteris et al. (2014) present rBC records from three high-accumulation West Antarctic ice cores: Pine Island Glacier, Thwaites Glacier and the divide between the two sites $(220,750$ and $370 \mathrm{~km}$ apart from TT07 core, respectively). The cores presented annual $\mathrm{rBC}$ concentrations of 0.22 (Pine Island), 0.21 (Thwaites) and $0.20 \mu \mathrm{g} \mathrm{L}^{-1}$ (Divide). The lower-altitude cores (DIV2010 - $1329 \mathrm{~m}$ a.s.l. and PIG2010 - $1593 \mathrm{~m}$ a.s.l.) presented almost 1.5 times more 


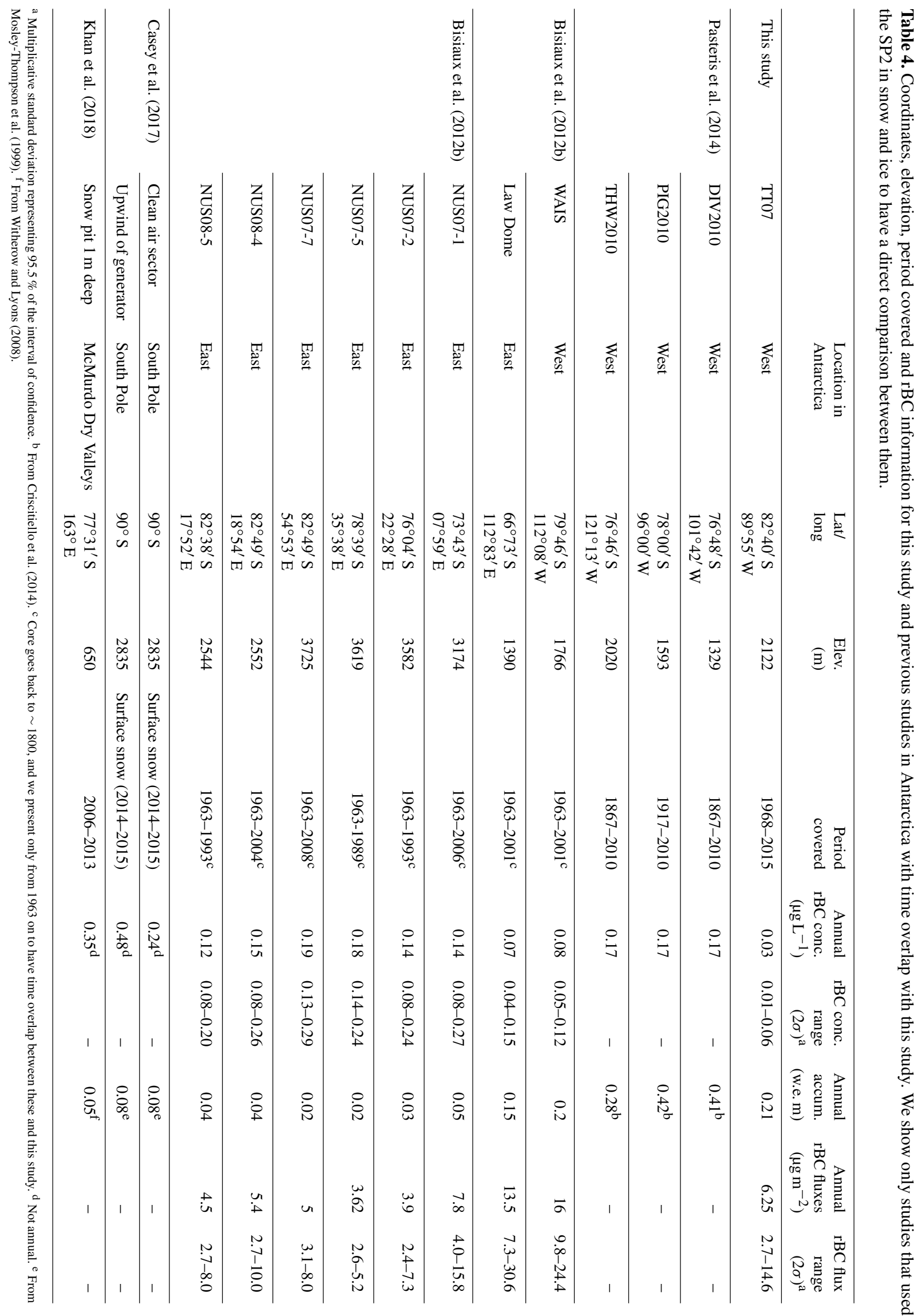



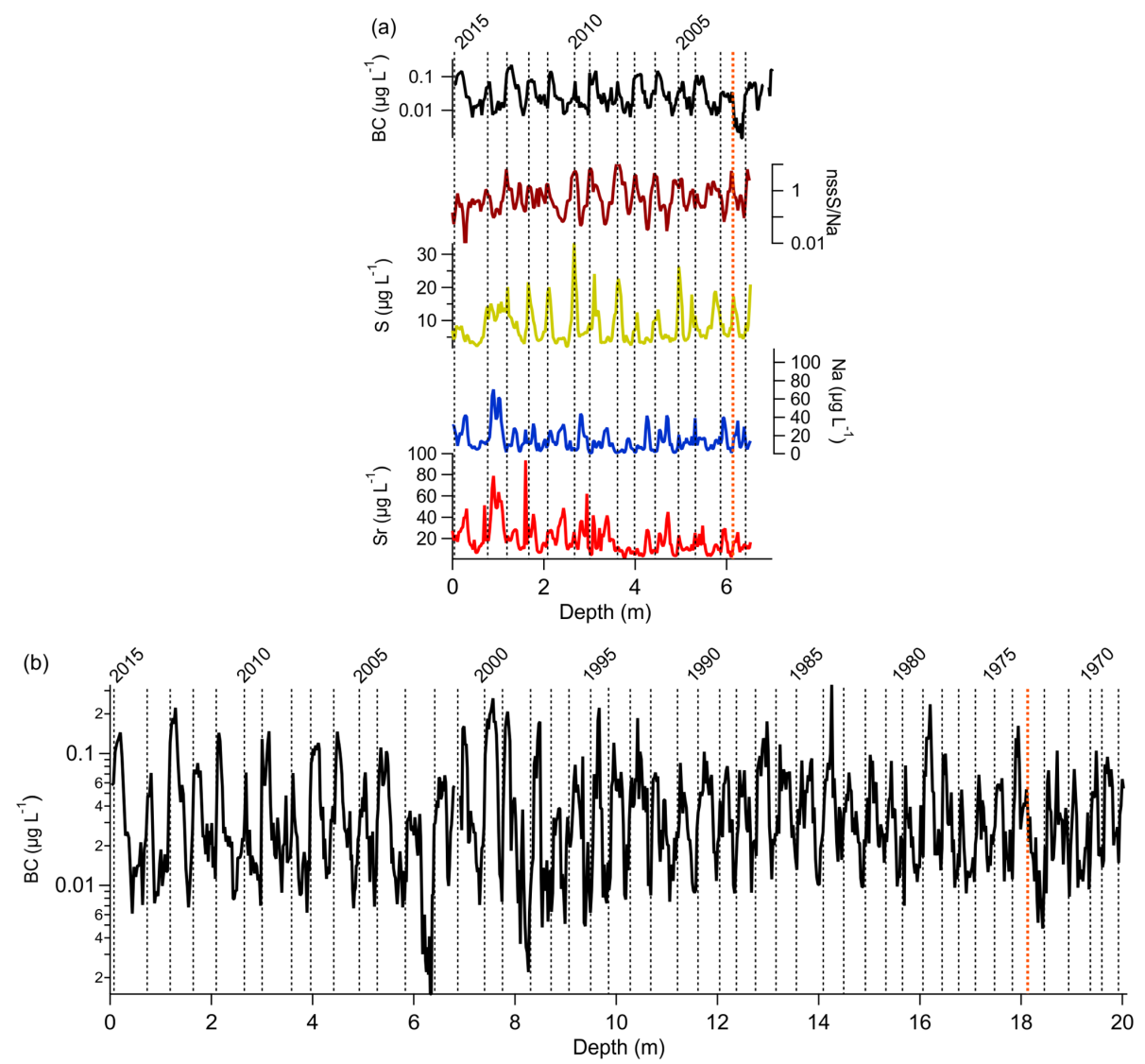

Figure 2. (a) Dating of the snow and firn core based on $\mathrm{rBC}$ and using $\mathrm{S}, \mathrm{Sr}$, Na and nss / Na records from a nearby core (see Sect. 3.6) as support for the first $6.5 \mathrm{~m}$. Dashed lines indicate the estimated New Year, and the red dotted line indicates uncertainty in dating, explained in the text. (b) Dating for the full core ( $y$ axis is logarithmic). The red dotted line indicates uncertainty in dating, as explained in the text.

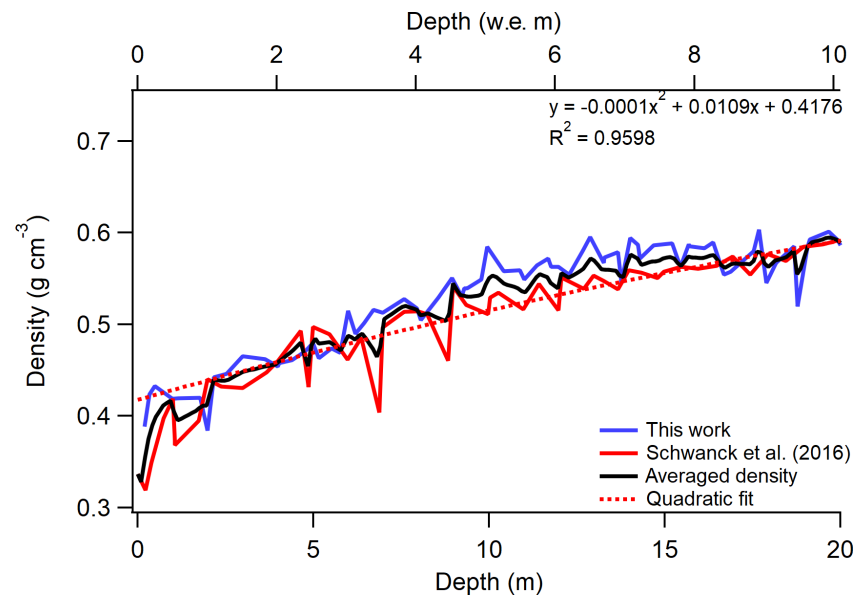

Figure 3. TT07 density profile (blue). Depth is presented in meters and water equivalent (w.e.) meters. The quadratic fit was calculated from the average density profile (black) from this work and from Schwanck et al. (2016b).

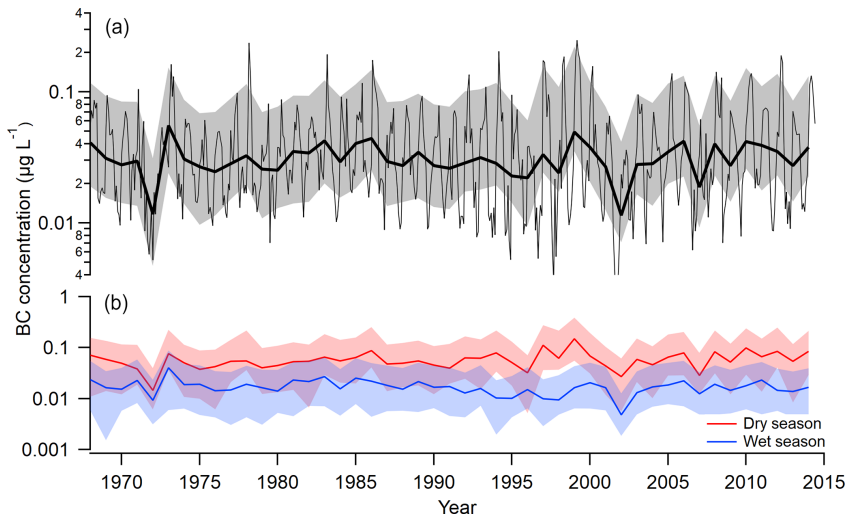

Figure 4. (a) $\mathrm{rBC}$ concentrations for the entire core. The thick black line represents annual averages, while the gray line represents monthly values. Note the $y$-axis scale is logarithmic. (b) Dry season and wet season average concentrations per year. 


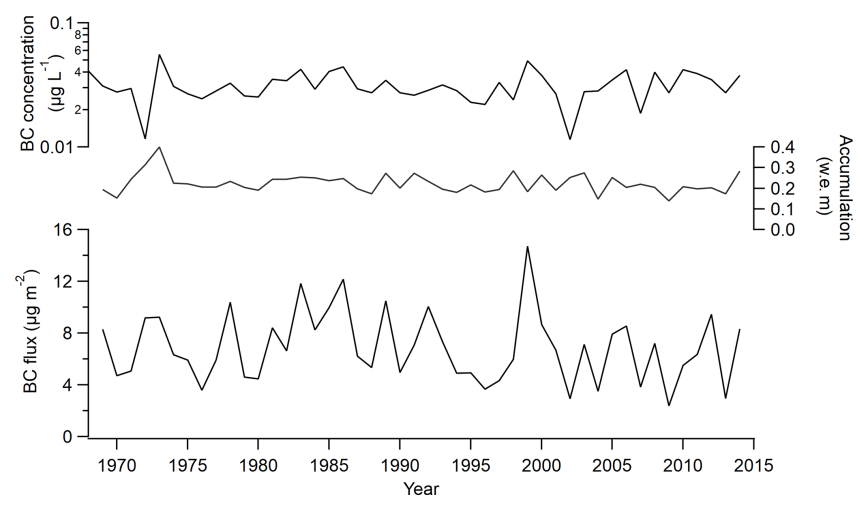

Figure 5. $\mathrm{rBC}$ concentrations ( $y$ axis is logarithmic), accumulation and fluxes for TT07.

snow accumulation than the higher-altitude core (THW2010 - 2020 ma.s.l.) and almost 2 times more than TT07. The mean annual rBC concentrations from Pasteris et al. (2014) are almost 6 times higher than the $\mathrm{rBC}$ annual values observed in TT07. Higher rBC concentrations in Pasteris et al. (2014) could be a result of higher accumulation rates, considering that $\mathrm{BC}$ is primarily deposited through wet deposition (Flanner et al., 2007). This is discussed later on in this section.

The WAIS Divide rBC record from Bisiaux et al. (2012a) is located $350 \mathrm{~km}$ away from TT07, has similar accumulation rates to TT07 and $\mathrm{rBC}$ annual concentration 2.7 times higher than annual values from TT07 $(0.08 \mu \mathrm{g} \mathrm{L}-1$ at WAIS and $0.03 \mu \mathrm{g} \mathrm{L}^{-1}$ at TT07). The authors observed a steep increase in rBC concentrations in the WAIS core from 1970 to $2001(\sim 0.06$ to $\sim 0.11 \mu \mathrm{g} \mathrm{L}-1)$ and related this to an increase in fossil fuel consumption and deforestation in the SH. This increasing trend was not observed in the TT07 core, which showed fairly stable annual concentrations and fluxes through time. Although the WAIS Divide core is located almost at the same distance from TT07 as DIV2010, and farther than PIG2010, its snow accumulation rates and rBC annual concentrations are more similar to TT07 than the cores from Pasteris et al. (2014).

The South Pole samples (1120 km from TT07) from Casey et al. (2017) were collected in early austral summer, possibly still reflecting the SH dry season. They present even higher rBC concentrations than Pasteris et al. (2014), although the samples were collected close to the Amundsen-Scott scientific station, and even the "clean air sector" can present local influence, particularly in comparison to the TT07 remote site.

Khan et al. (2018) found rBC concentrations on the same order of magnitude as Casey et al. (2017), although the Dry Valleys collection site from Khan et al. (2018) was far from local interference of scientific station activities. The cores from Bisiaux et al. (2012b) (East Antarctica) present the highest elevations from the cited bibliography and show similar rBC fluxes compared to TT07, although these fluxes are

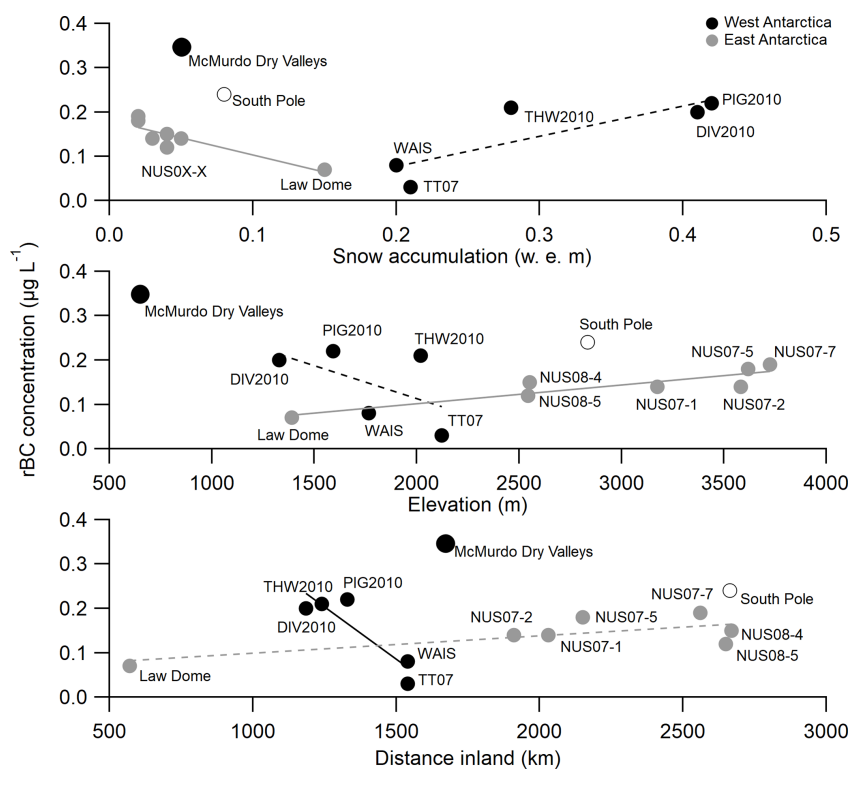

Figure 6. $\mathrm{rBC}$ records from Antarctica. $\mathrm{rBC}$ concentrations plotted against snow accumulation, elevation and distance from the sea. Solid lines indicate statistically significant correlations $(p<0.05)$, while dashed lines indicate not significant correlations $(p>0.05)$.

a result of high $\mathrm{rBC}$ concentrations with low accumulation rates in East Antarctica, while the TT07 fluxes are the opposite - high accumulation rates (similar to the WAIS Divide core) with low rBC concentrations.

Figure 6 shows a comparison of the abovementioned rBC records with snow accumulation, elevation and distance from the open sea. Distance from the sea influences rBC fluxes in West Antarctica (Arienzo et al., 2017) and was calculated considering the median sea ice extent from 1981 to 2010 for September (Matsuoka et al., 2018), when rBC emissions start to rise in South America-Australia-New Zealand and rBC concentrations begin to rise in West Antarctica (Arienzo et al., 2017; Bisiaux et al., 2012b; Pasteris et al., 2014). We measured the distance from the $\mathrm{rBC}$ records to the closest open sea source (Amundsen Sea for West Antarctic records, Lazarev to Cosmonauts seas for NUSOX-X, and Mawson Sea for Law Dome). We acknowledge this is a simplistic approximation and that the preferred air mass pathways from the sea to the points are not as straightforward, but for the scope of this work we consider this approximation sufficient.

No patterns are clear for both East and West Antarctica, whereas when considering the data from East and West Antarctica separately, opposite trends are observed. In East Antarctica, rBC concentrations have a negative correlation with snow accumulation and positive correlation with elevation and distance to the sea, whereas in West Antarctica rBC concentrations present a positive correlation with snow accumulation and a negative correlation with elevation and distance to the sea. We observed that for East Antarctica, rBC vs. snow accumulation and $\mathrm{rBC}$ vs. elevation presented sta- 
tistically significant correlations $\left(r^{2}=0.78, p<0.01\right.$ for the former and $r^{2}=0.79, p<0.01$ for the latter). On the other hand, distance from the sea is not significantly correlated with $\mathrm{rBC}\left(r^{2}=0.52, p=0.06\right)$.

For West Antarctica, relationships are the opposite: positive correlation between $\mathrm{rBC}$ concentrations and snow accumulation $\left(r^{2}=0.69, p=0.08\right)$ and negative correlations between $\mathrm{rBC}$ concentrations and elevation and distance from the sea $\left(r^{2}=0.30, p=0.33\right.$ for the former and $r^{2}=0.79$, $p<0.05$ for the latter). Only the correlation between rBC vs. distance from the sea, though, is statistically significant. McMurdo and South Pole points are not considered in this calculation as they likely reflect local contamination instead of long-range transport (Casey et al., 2017; Khan et al., 2018). Bisiaux et al. (2012b) have also observed negative (positive) relationships between rBC concentrations and snow accumulation (elevation) for East Antarctica, although their comparison also included the WAIS Divide point in the dataset.

These opposite trends may indicate differences in $\mathrm{rBC}$ transport to East and West Antarctica. While for East Antarctica upper-tropospheric transport and dry deposition may be the main controllers of $\mathrm{rBC}$ concentrations (Bisiaux et al., 2012b), for West Antarctica rBC concentrations may be modulated by intrusion of air masses from the marine boundary layer. Low elevations in West Antarctica facilitates the intrusion of moisture-rich cyclones and the transport of aerosols inland (Neff and Bertler, 2015; Nicolas and Bromwich, 2011), while the positive relationship between West Antarctica $\mathrm{rBC}$ concentrations and snow accumulation may indicate $\mathrm{rBC}$ to be primarily deposited through wet deposition, being scavenged along the coastal regions where snow accumulation is higher.

\subsection{BC impact on snow albedo}

To investigate BC impact on snow albedo we used SNICAR online to simulate three scenarios with the same parameters but varying $\mathrm{rBC}$ concentrations. We ran the model using the wet and dry season geomeans and the highest seasonal geomean $\left(0.015,0.057\right.$ and $0.105 \mu \mathrm{g} \mathrm{L}{ }^{-1}$, respectively). Results show that snow albedo reduction at the TT07 site due to BC is very low to nonexistent (Table 5). This was already expected considering (observed) albedo reported by Casey et al. (2017). Although significant albedo reductions have been reported in more contaminated zones near the South Pole Station, the authors found a minor to negligible reduction in albedo for the "clean sector" snow.

We note that this albedo reduction occurs only in the austral summer, as the site is located almost at $80^{\circ} \mathrm{S}$.

\subsection{Emission sources and influence of transport on the record}

Variability in ice core records reflects variability in BC emissions, atmospheric transport and deposition (Bisiaux et al.,
Table 5. Albedo changes due to rBC concentrations at the TT07 site (from SNICAR online).

\begin{tabular}{llr}
\hline $\begin{array}{l}\text { Concentration } \\
\left(\mu \mathrm{g} \mathrm{L}^{-1}\right)\end{array}$ & Reference & $\begin{array}{r}\text { Albedo } \\
\text { variation } \\
\text { (relative to } \\
\text { clean snow) }\end{array}$ \\
\hline 0.015 & Wet season geomean & 0 \\
0.057 & Dry season geomean & $-0.41 \%$ \\
0.105 & Highest seasonal geomean & $-0.48 \%$ \\
\hline
\end{tabular}

2012a). As BC stays in the atmosphere for a short period of time (7 to $10 \mathrm{~d}$; IPCC et al., 2013), increases in BC emissions would rapidly reflect increases in $\mathrm{BC}$ concentrations in snow, and thus comparing the seasonality of the two records may help to elucidate source regions. To this end, we compared BC monthly emissions in the SH (from the GFED4s model) with monthly rBC values from the TT07 record (Fig. 7a). The BC seasonality at TT07, with increasing concentrations in July, a peak in October and minimum values in April-May, is the same as reported for the nearby Pine Island Glacier (Pasteris et al., 2014; Fig. 1), indicating that comparing the TT07 seasonality to regional emissions is valid.

Some models indicate that the carbonaceous load in the Antarctic troposphere mainly originates from South American emissions (Koch et al., 2007); others recognize both South America and Australia as the main sources (Stohl and Sodemann, 2010). Although southern Africa has the largest $\mathrm{BC}$ emissions in the $\mathrm{SH}$, it is not considered to be a significant contributor to the aerosol load in Antarctica ( $\mathrm{Li}$ et al., 2008; Neff and Bertler, 2015; Stohl and Sodemann, 2010). Both Australia (Bisiaux et al., 2012a) and South America (Arienzo et al., 2017) have been suggested as sources of BC to West Antarctica.

Figure $7 \mathrm{a}$ shows the $\mathrm{rBC}$ monthly-average values for TT07 (1968-2014) and monthly-averaged BC emissions from GFED4s (1997-2015) for the four SH emission regions (regions defined in GFED4s; see website). rBC in the TT07 starts increasing considerably in July, peaks in October and shows high but decreasing concentrations until December.

African emissions increase and decrease earlier in the year compared with other SH emission sources and with the TT07 $\mathrm{BC}$ record (Kendall's tau $=0.30, p=0.17, n=12$ ). Equatorial Asia BC emissions increase in August and peak in September, not reflecting the initial $\mathrm{rBC}$ increase in TT07 record (Kendall's tau $=0.33, p=0.13, n=12$ ). The increasing trend matches South American emissions, as they start rising in the same period, although peaking in September and dropping significantly after (Kendall's tau $=0.66, p<0.01$, $n=12$ ). At last, Australia and New Zealand emit much less $\mathrm{BC}$ than the other three regions (Fig. 7b) but atmospheric circulation favors aerosol transport from there to West Antarctica (Li et al., 2008; Neff and Bertler, 2015). Australian and 

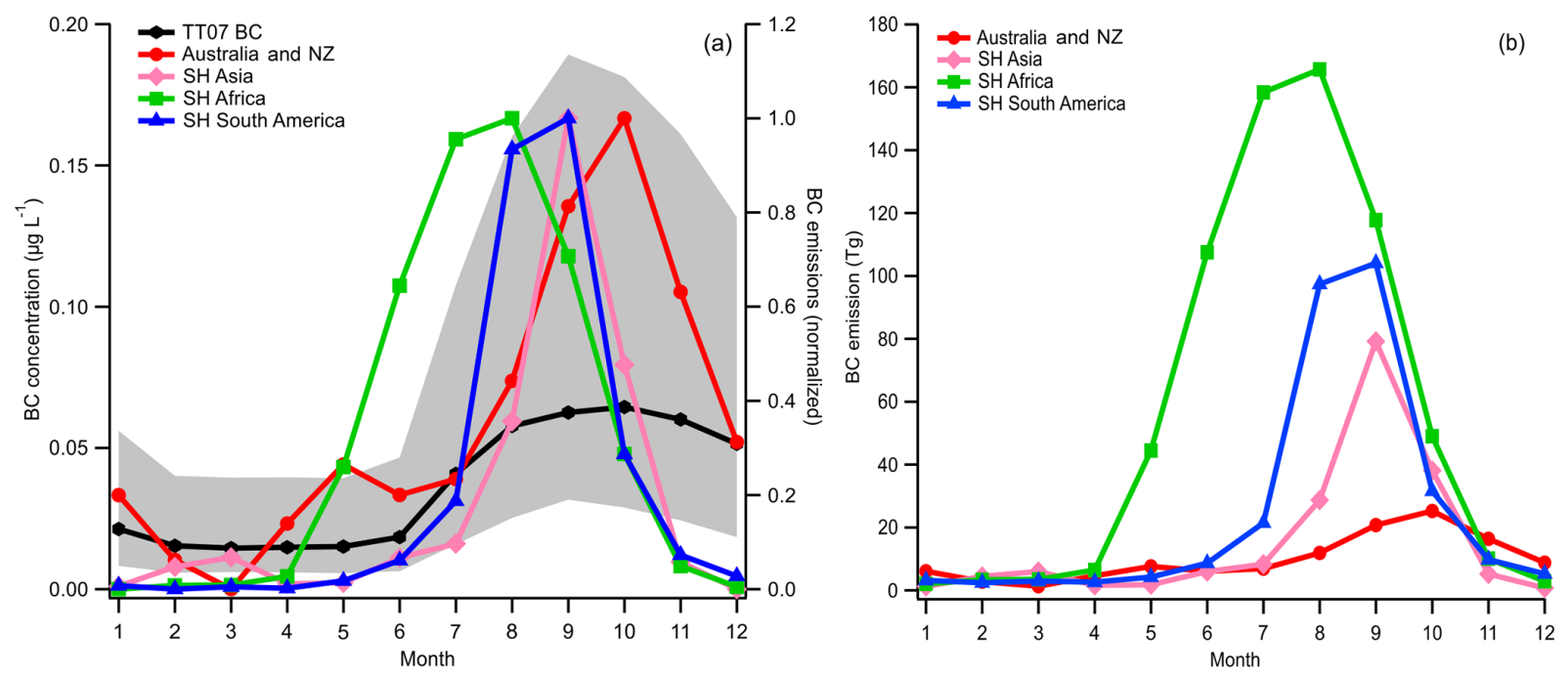

Figure 7. (a) TT07 rBC (monthly averages, 1968-2014) and BC emissions estimated from GFED4s for the four SH regions (normalized, 1997-2014). The shaded area represents 1 geometric standard deviation of monthly rBC values. (b) Absolute BC emissions estimated from GFED4s for the SH.

New Zealand emissions start increasing in August and peak in October, falling later than the other regions (December) (Kendall's tau $=0.85, p<0.01, n=12$ ). The correlation coefficients then indicate Australia-New Zealand as the most probable source region for $\mathrm{BC}$ at the site for the period studied, followed by SH South America. SH Africa and Equatorial Asia present much weaker correlations, which likely indicates these two regions do not contribute substantially to the rBC flux to the TT07 site. This is consistent with previous research (Arienzo et al., 2017; Bisiaux et al., 2012a).

There is a small increase in Australian emissions earlier in the year (May) that is not observed in the TT07 rBC monthly averages. This difference could be associated with the seasonal difference in particulate transport to Antarctica in winter-summer (Hara et al., 2008; Schwanck et al., 2017; Stohl and Sodemann, 2010).

\subsection{Spectral analysis}

We further investigated the possible emission sources and transport influences to the site using the REDFIT spectral analysis. We compared the $\mathrm{rBC}$ record with ENSO, AAO and ASL indexes (Fig. 8). This investigation would give information about the effect of local to regional changes in atmospheric circulation on the BC records (Bisiaux et al., 2012a).

The TT07 rBC spectrum showed significant cycles in the 6-year band (AR1 confidence interval, CI >90\%) and in the 2-year band (AR1 CI $\sim 90 \%$ ). Intra-annual cycles in the 0.6 and 0.5 frequencies were also observed at a $95 \%$ confidence interval. Comparing the TT07 $\mathrm{rBC}$ record spectrum with the GFED4s and fire spot spectra, we identified similar periodicities only in the Sentinel Hotspots (Australia) record (Fig. 8), more specifically in the 2-year band (AR1 CI 90\%) and in the 0.6-year band (AR1 CI $>90 \%$ ). All other spectra (including Programa Queimadas satellite data) showed only wellmarked annual periodicities and intra-annual periodicities of two and three cycles per year (0.5- and 0.3-year bands, not shown). We consider some of these intra-annual cycles questionable, as the high-frequency end of the spectrum is often overestimated and can present aliases, "folded signals", of another frequency process (Mudelsee, 2010; Schulz and Mudelsee, 2002), in this case aliases of the annual cycle at the 0.5- and 0.3-year bands. Due to this, we do not consider 0.5 - and 0.3-year cycles to be representative.

$\mathrm{rBC}$ and AAO present similar cycles (2.1- and 0.6-year bands), as well as rBC and ENSO (2-year band).

Using the multitaper method, Bisiaux et al. (2012a) observed the $\mathrm{rBC}$ periodicities for the WAIS Divide ice core and Law Dome (both dated to 1850-2001). Although WAIS is closer to the TT07 drilling site $(\sim 350 \mathrm{~km})$, the TT07 core presented similarities with the Law Dome spectrum (in the 6- and 2-year bands, not shown). It is not clear to us what the relation between the two sites could be, as the TT07 site location, annual accumulation and site elevation are more related to the WAIS ice core than to Law Dome (Table 4). Arienzo et al. (2017) used the multitaper method to analyze the WAIS Divide rBC flux for the period spanning 14-6 kyr BP and found a 6.6-year cycle (AR1 CI $=95 \%$ ) and a 2.3-year cycle (AR1 CI $>95 \%$ ), similar to the $\mathrm{rBC}$ cycles found in this work; although timescales and methodology used were different. Both Arienzo et al. (2017) and Bisiaux et al. (2012a) attribute the 2.3-year cycle to an indirect effect of the QuasiBiennial Oscillation (QBO). Although the QBO circulation spans the Equator to $\sim 30^{\circ}$, QBO-generated variability can affect Antarctica (Strahan et al., 2015), in which case an 

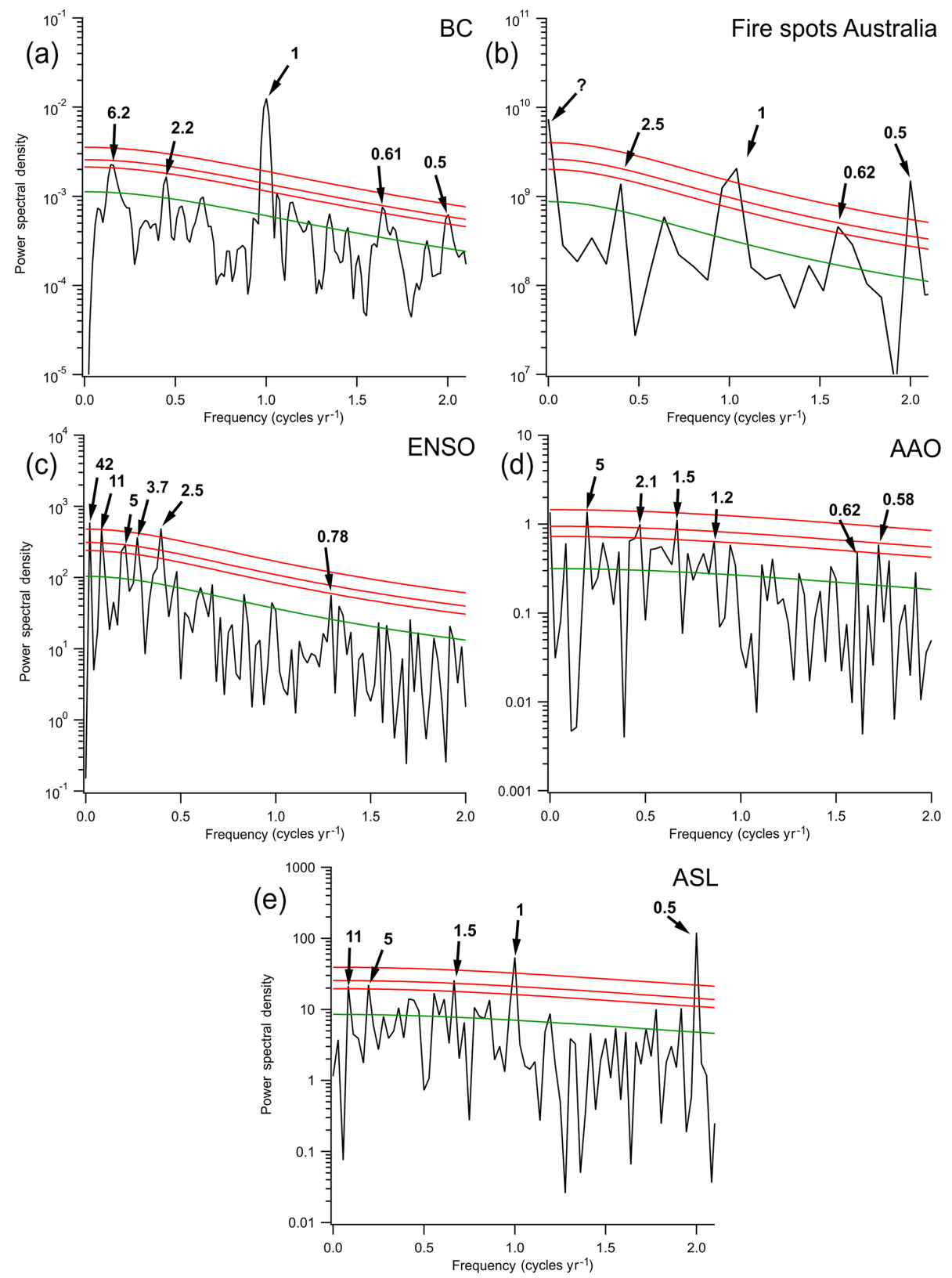

Figure 8. Spectral analysis of the rBC concentrations and comparison with existing datasets (Sentinel Hotspots Australia, ASL, AAO and ENSO indexes). Numbers in bold indicate cycle frequency, in years. Red lines are confidence intervals $99 \%$ (a, b), $95 \%$ (c, d) and $90 \%$ (e). The green line indicates the AR1 red-noise background. The question mark in the Australian fire spot spectrum indicates a longer unidentified cycle.

upper-troposphere-stratospheric component may be important for BC transport to the continent.

In summary, the spectral analysis suggests Australia and New Zealand as the most probable sources of $\mathrm{rBC}$ to the drilling site. Also, rBC seems to be related to the AAO (0.6and 2-year cycle) and to ENSO (2-year cycle) but not to ASL, and similarities between rBC cycles at the TT07 site and the WAIS Divide site have been observed.

\subsection{Particle trajectory simulations using HYSPLIT}

We simulated particle transport during the austral wet and dry seasons as another mean of addressing $\mathrm{rBC}$ source areas. We ran the HYSPLIT back-trajectory model every $5 \mathrm{~d}$ from 1968 to 2015, for $10 \mathrm{~d}$ each (estimated maximum BC lifetime in the troposphere) and clustered the results in five groups for the wet and dry seasons (Fig. 9). 


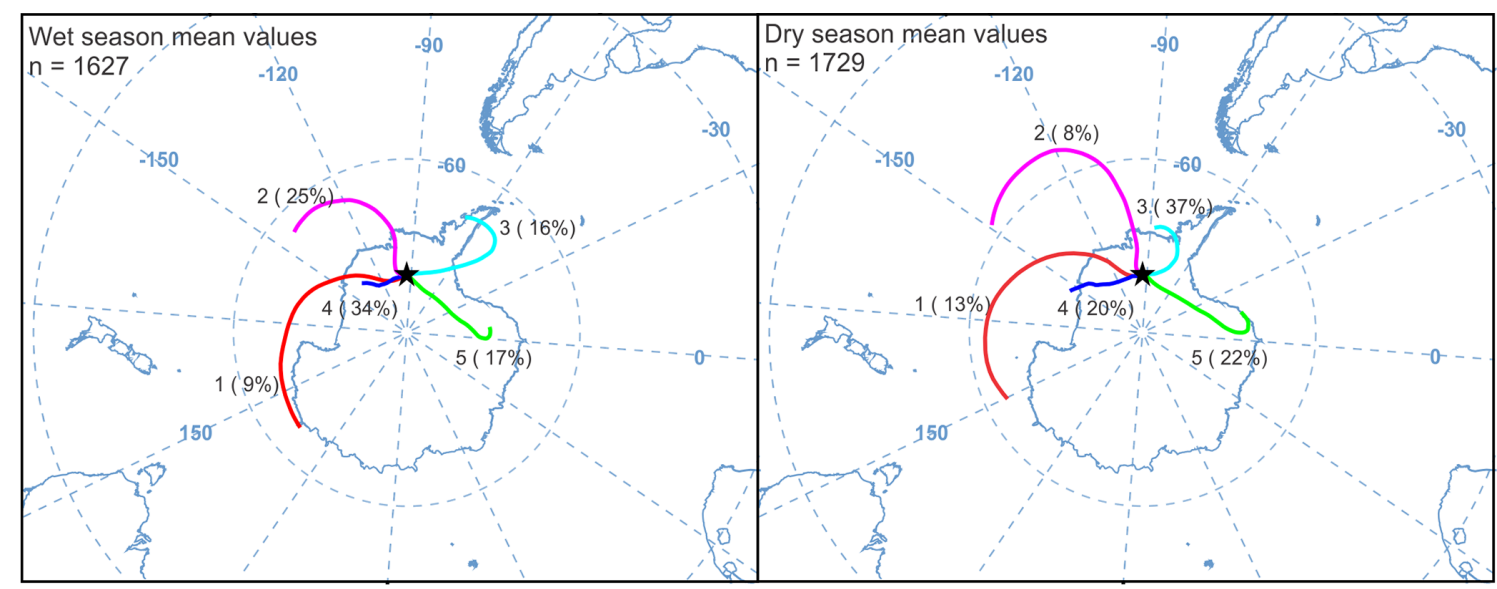

Figure 9. HYSPLIT clusters of $10 \mathrm{~d}$ back trajectories run every $5 \mathrm{~d}$ from 1968 to 2015 arriving at the TT07 drilling site. Results are separated by wet and dry seasons and grouped in five clusters (percentage of trajectories for each cluster is shown in parentheses). Number of trajectories ( $n$ ) used for the cluster algorithm is shown at the top, on the left side.
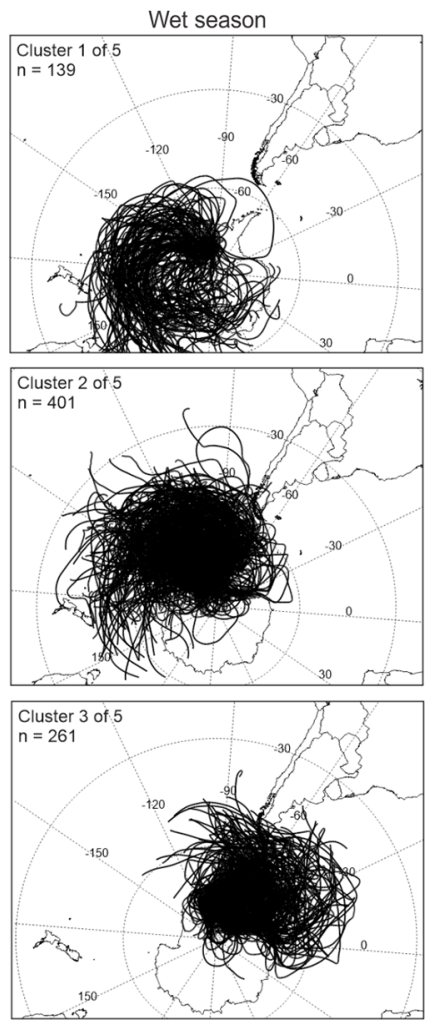
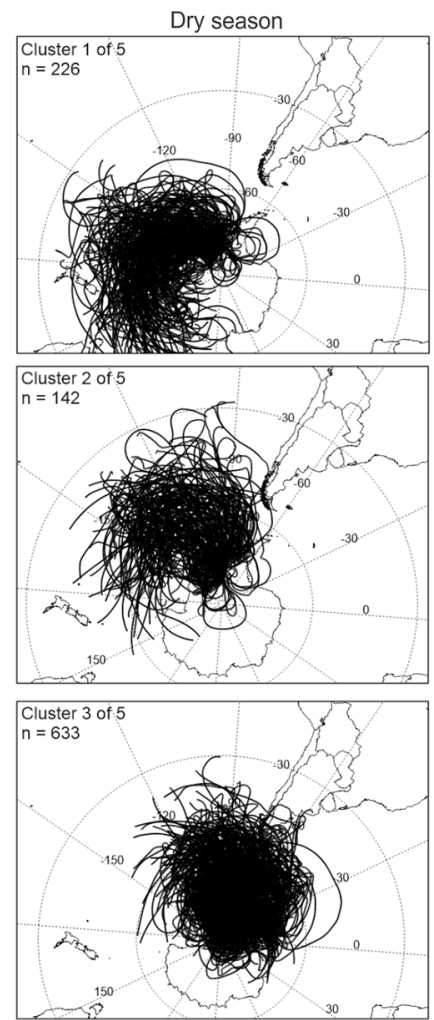
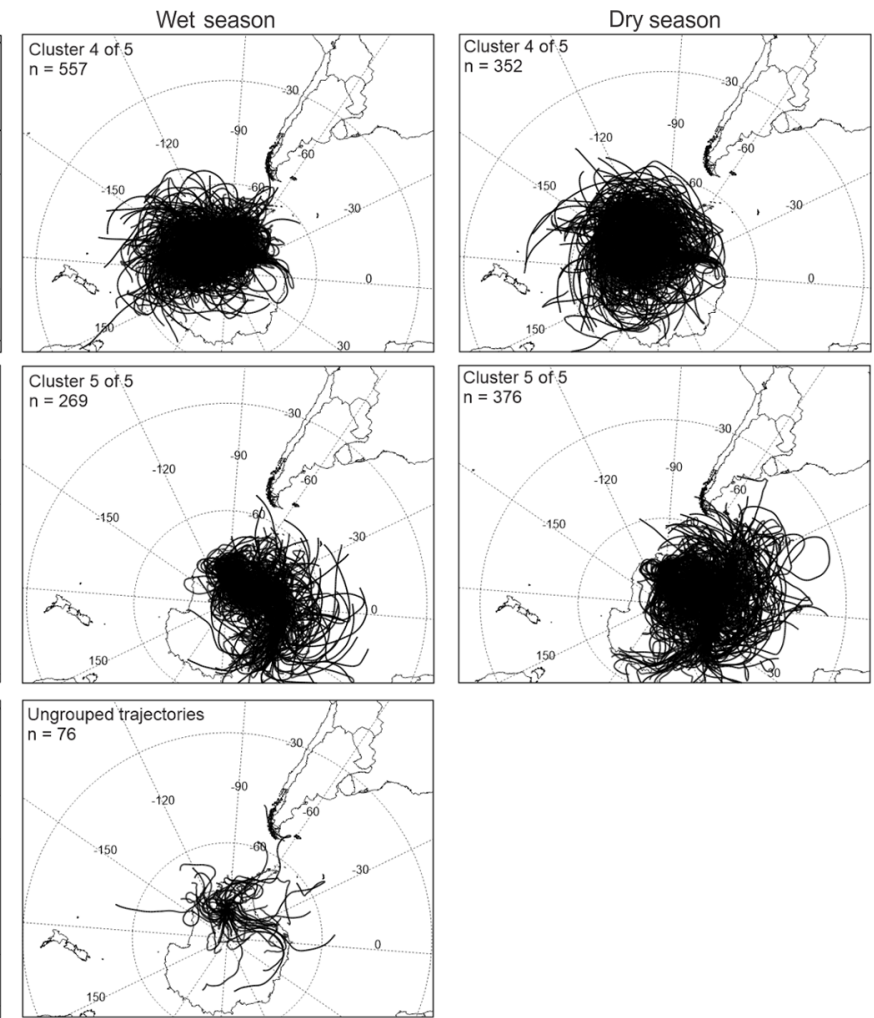

Figure 10. Individual trajectories used for the cluster analysis in Fig. 8. Number of trajectories $(n)$ used for each cluster is shown at the top, on the left side. Clusters 1, 2 and 4 show air masses arriving from Australia and New Zealand to the TT07 drilling site, while clusters 2, 3 and 4 show the (limited) contribution of South American air parcels to the site. Similar clusters from the wet and dry seasons are side by side for comparison. The wet season presented 76 ungrouped trajectories, while the dry season presented none.

A significant part of the simulated air parcels arriving at the drilling site $(50 \%$ in the wet season and $57 \%$ in the dry season) presented a slow-moving trajectory (speed is proportional to trajectory length), reflecting a local and/or regional influence more than long-range transport from other conti- nents (clusters 3 and 4 in Fig. 9). This local and/or regional influence is observed in both the wet and dry seasons, although during the former the contribution of air masses from the Antarctic Peninsula and across the Weddell Sea is higher than during the latter. A fast-moving, year-round continen- 
tal group is also present (cluster 5) and may partly represent katabatic winds flowing from the continent's higher altitudes (East Antarctica) towards lower-altitude West Antarctica. The strongest contribution of long-range air parcels is from the South Pacific (clusters 1 and 2). These air masses are also fast-moving and present slight seasonal variations, shifting poleward during the wet season, when they represent $34 \%$ of all air parcels, and away from Antarctica during the dry season, when they respond for $22 \%$ of all air parcels modeled.

Results from clusters 1 and 2, along with individual trajectories of each cluster (Fig. 10) support our conclusion that Australia and New Zealand are the most probable sources of $\mathrm{rBC}$ to the drilling site, considering tropospheric transport. The most visible influence of air parcels from these two countries to the drilling site can be seen in the individual trajectories of cluster 1 (Fig. 10) for both dry and wet seasons, while for clusters 2 and 4 there are trajectory variations from one season to another. The poleward shift of cluster 1 trajectories in the wet season (Fig. 9) may be a reason why the Australian emissions earlier in the year (May) are not visible in the TT07 rBC record. South American influence on the TT07 drilling site, on the other hand, is restricted to the higher-latitude countries (Chile, Argentina), as shown in the individual trajectories of clusters 2, 3 and 5 (Fig. 10). This suggests that South American fires are not significant contributors to the rBC concentrations observed at the TT07 site when considering only tropospheric transport.

\section{Conclusions}

BC in Antarctica has been studied only in the recent decades, but long-range anthropogenic influences have already been observed (Bisiaux et al., 2012a; Stohl and Sodemann, 2010). Models predict a continued increase in $\mathrm{BC}$ emissions from source areas (Bond et al., 2013) and a continued increase in BC flux to the Antarctic region, mostly to the Antarctic Peninsula and West Antarctica (Arienzo et al., 2017). Understanding the spatial variability of $\mathrm{BC}$ is then essential to predict BC's future impact on the continent.

We analyzed a $20 \mathrm{~m}$ long snow-firn core from West Antarctica spanning 1968-2015 for rBC. Results show a well-defined seasonal variability in the record, with low (high) concentrations during the Southern Hemisphere wet (dry) season but no long-term trend along the 47 years of the core. Snow accumulation remained stable during this period. $\mathrm{rBC}$ annual concentrations were found to be the lowest in samples from recent decades compared to other studies, while $\mathrm{rBC}$ annual fluxes compare with the low values found by Bisiaux et al. (2012b) for high-elevation East Antarctica ice cores. Correlations between $\mathrm{rBC}$ and snow accumulation, elevation and distance to the sea for East and West Antarctica records indicate $\mathrm{rBC}$ transport and deposition might be different for each. SNICAR modeling indicated BC does not affect snow albedo significantly at the site, with a reduction of $0.48 \%$ and $0.41 \%$ for the highest $\mathrm{rBC}$ concentrations found in the core and for dry season geomean concentrations relative to clean snow, respectively. Negligible impact on albedo was observed for wet season geomean concentrations. BC emission estimates, satellite data of fire spots and HYSPLIT particle transport simulations suggest Australia and New Zealand as the main contributors to the $\mathrm{rBC}$ present in the TT07. Based on GFED4s emission estimates, SH South America may be a secondary contributor, although this is not supported by spectral analysis results or air mass trajectories. Spectral analysis of the rBC shows influence of AAO and ENSO periodicities; ASL influences were not detected. This core is the highest-elevation $\mathrm{rBC}$ core collected in West Antarctica and its low BC concentrations compared to previous studies indicate spatial variability in the transport and deposition of $\mathrm{BC}$ in West Antarctica.

Data availability. TT07 data are available upon request; auxiliary data can be downloaded from respective sources cited along with this work.

Author contributions. This work was conceptualized by all authors. Funding was acquired by JCS, who also administered the project. JCS and LM participated on the fieldwork, while laboratory work was done by LM supervised by SK. LM wrote the original draft with contributions from SK and JCS. All authors contributed to the interpretation of study results.

Competing interests. The authors declare that they have no conflict of interest.

Acknowledgements. We thank the Centro Polar e Climático (CPC/UFRGS) and the Department of Geological Sciences (CWU) faculty and staff for the support of this work. We also thank the authors Bisiaux et al. (2012a, b), Casey et al. (2017), Khan et al. (2018) and Pasteris et al. (2014) for rBC data availability.

Financial support. This research is part of the Brazilian Antarctic Program (PROANTAR) and was financed with funds from the Brazilian National Council for Scientific and Technological Development (CNPq) Split Fellowship Program (no. 200386/20182), from the CNPq projects 465680/2014-3 and 442761/2018-0, CAPES project "INCT da Criosfera" 88887.136384/2017-00 and PROANTAR project 88887.314450/2019-00.

Review statement. This paper was edited by Mark Flanner and reviewed by two anonymous referees. 


\section{References}

AMAP: Arctic Monitoring and Assessment Programme (AMAP) assessment 2015: Black carbon and ozone as Arctic climate forcers, VII, Oslo, Norway, 2015.

Andela, N., Morton, D. C., Giglio, L., Chen, Y., van der Werf, G. R., Kasibhatla, P. S., DeFries, R. S., Collatz, G. J., Hantson, S., Kloster, S., Bachelet, D., Forrest, M., Lasslop, G., Li, F., Mangeon, S., Melton, J. R., Yue, C., and Randerson, J. T.: A humandriven decline in global burned area, Science, 356, 1356-1362, https://doi.org/10.1126/science.aal4108, 2017.

Arienzo, M. M., McConnell, J. R., Murphy, L. N., Chellman, N., Das, S., Kipfstuhl, S., and Mulvaney, R.: Holocene black carbon in Antarctica paralleled Southern Hemisphere climate, J. Geophys. Res., 122, 6713-6728, https://doi.org/10.1002/2017JD026599, 2017.

Banta, J. R., McConnell, J. R., Frey, M. M., Bales, R. C., and Taylor, K.: Spatial and temporal variability in snow accumulation at the West Antarctic Ice Sheet Divide over recent centuries, J. Geophys. Res.-Atmos., 113, D23102, https://doi.org/10.1029/2008JD010235, 2008.

Bice, K., Eil, A., Habib, B., Heijmans, P., Kopp, R., Nogues, J., Norcross, F., Sweizer-Hamilton, M., and Whitworth, A.: Black carbon: A review and policy recommendations, Princeton, NJ, EUA, available at: http: //scholar.google.com/scholar?hl=en\&btnG=Search\&q=intitle: Black+Carbon:+A+Review+and+Policy+recommendations\#0 (last access: 15 July 2019), 2009.

Bisiaux, M. M., Edwards, R., McConnell, J. R., Curran, M. A. J., Van Ommen, T. D., Smith, A. M., Neumann, T. A., Pasteris, D. R., Penner, J. E., and Taylor, K.: Changes in black carbon deposition to Antarctica from two high-resolution ice core records, 1850-2000 AD, Atmos. Chem. Phys., 12, 4107-4115, https://doi.org/10.5194/acp-12-4107-2012, 2012a.

Bisiaux, M. M., Edwards, R., McConnell, J. R., Albert, M. R., Anschütz, H., Neumann, T. A., Isaksson, E., and Penner, J. E.: Variability of black carbon deposition to the East Antarctic Plateau, 1800-2000 AD, Atmos. Chem. Phys., 12, 3799-3808, https://doi.org/10.5194/acp-12-3799-2012, 2012b.

Bond, T. C., Doherty, S. J., Fahey, D. W., Forster, P. M., Berntsen, T., Deangelo, B. J., Flanner, M. G., Ghan, S., Kärcher, B., Koch, D., Kinne, S., Kondo, Y., Quinn, P. K., Sarofim, M. C., Schultz, M. G., Schulz, M., Venkataraman, C., Zhang, H., Zhang, S., Bellouin, N., Guttikunda, S. K., Hopke, P. K., Jacobson, M. Z., Kaiser, J. W., Klimont, Z., Lohmann, U., Schwarz, J. P., Shindell, D., Storelvmo, T., Warren, S. G., and Zender, C. S.: Bounding the role of black carbon in the climate system: A scientific assessment, J. Geophys. Res.-Atmos., 118, 5380-5552, https://doi.org/10.1002/jgrd.50171, 2013.

Casey, K. A., Kaspari, S. D., Skiles, S. M., Kreutz, K., and Handley, M. J.: The spectral and chemical measurement of pollutants on snow near South Pole, Antarctica, J. Geophys. Res.-Atmos., 122, 6592-6610, https://doi.org/10.1002/2016JD026418, 2017.

Chýlek, P., Srivastava, V., Cahenzli, L., Pinnick, R. G., Dod, R. L., Novakov, T., Cook, T. L., and Hinds, B. D.: Aerosol and graphitic carbon content of snow, J. Geophys. Res., 92, 9801, https://doi.org/10.1029/JD092iD08p09801, 1987.

Chýlek, P., Johnson, B., Wu, H.: Black carbon concentration in Byrd Station ice core - From 13,000 to 700 years before present, Ann. Geophys. Atmos. Hydros. Space Sci, 10, 625-629, 1992.
Dixon, D. A., Mayewski, P. A., Goodwin, I. D., Marshall, G. J., Freeman, R., Maasch, K. A., and Sneed, S. B.: An ice-core proxy for northerly air mass incursions into West Antarctica, Int. J. Climatol., 32, 1455-1465, https://doi.org/10.1002/joc.2371, 2011.

Draxler, R. R. and Rolph, G. D.: HYSPLIT (HYbrid Single Particle Lagrangian Integrated Trajectory) Model access via NOAA ARL READY Web site, available at: http://www.arl.noaa.gov/ready/ hysplit4.html (last access: 5 March 2020), NOAA Air Resour. Lab. Silver Spring, Md., 2003.

Fiebig, M., Lunder, C. R., and Stohl, A.: Tracing biomass burning aerosol from South America to Troll Research Station, Antarctica, Geophys. Res. Lett., 36, 1-5, https://doi.org/10.1029/2009GL038531, 2009.

Flanner, M. G., Zender, C. S., Randerson, J. T., and Rasch, P. J.: Present-day climate forcing and response from black carbon in snow, J. Geophys. Res.-Atmos., 112, 1-17, https://doi.org/10.1029/2006JD008003, 2007.

Gay, M., Fily, M., Genthon, C., Frezzotti, M., Oerter, H., and Winther, J.-G.: Snow grain-size measurements in Antarctica, J. Glaciol., 48, 527-535, https://doi.org/10.3189/172756502781831016, 2002.

Ghil, M., Allen, M. R., Dettinger, M. D., Ide, K., Kondrashov, D., Mann, M. E., Robertson, A. W., Saunders, A., Tian, Y., Varadi, F., and Yiou, P.: Advanced spectral methods for climatic time series, Rev. Geophys., 40, 1-41, https://doi.org/10.1029/2000RG000092, 2002.

Giglio, L., Randerson, J. T., and Van Der Werf, G. R.: Analysis of daily, monthly, and annual burned area using the fourthgeneration global fire emissions database (GFED4), J. Geophys. Res.-Biogeo., 118, 317-328, https://doi.org/10.1002/jgrg.20042, 2013.

Hammer, Ø.: Past - Paleontological Statistics Version 3.25 reference manual, Natural History Museum, University of Oslo, Norway, 275 pp. 2019.

Hara, K., Osada, K., Yabuki, M., Hayashi, M., Yamanouchi, T., Shiobara, M., and Wada, M.: Measurement of black carbon at Syowa station, Antarctica: seasonal variation, transport processes and pathways, Atmos. Chem. Phys. Discuss., 8, 9883-9929, https://doi.org/10.5194/acpd-8-9883-2008, 2008.

Hosking, J. S., Orr, A., Marshall, G. J., Turner, J., and Phillips, T.: The influence of the amundsen-bellingshausen seas low on the climate of West Antarctica and its representation in coupled climate model simulations, J. Clim., 26, 6633-6648, https://doi.org/10.1175/JCLI-D-12-00813.1, 2013.

Hosking, J. S., Orr, A., Bracegirdle, T. J., and Turner, J.: Future circulation changes off West Antarctica: Sensitivity of the Amundsen Sea Low to projected anthropogenic forcing, Geophys. Res. Lett., 43, 367-376, https://doi.org/10.1002/2015GL067143, 2016.

IPCC: Stocker, T. F., Qin, D., Plattner, G.-K., Tignor, M., Allen, S. K., Boschung, J., Nauels, A., Xia, Y., Bex, V., and Midgley, P. M.: Climate Change 2013: The Physical Science Basis, Contribution of Working Group I to the Fifth Assessment Report of the Intergovernmental Panel on Climate Change, Cambridge e Nova Iorque, 2013.

Kaspari, S., Mayewski, P. A., Dixon, D. A., Spikes, V. B., Sneed, S. B., Handley, M. J., and Hamilton, G. S.: Climate variability in West Antarctica derived from annual accumulation-rate records from ITASE firn/ice cores, Ann. Glaciol., 39, 585-594, 2004. 
Kaspari, S., Painter, T. H., Gysel, M., Skiles, S. M., and Schwikowski, M.: Seasonal and elevational variations of black carbon and dust in snow and ice in the Solu-Khumbu, Nepal and estimated radiative forcings, Atmos. Chem. Phys., 14, 80898103, https://doi.org/10.5194/acp-14-8089-2014, 2014.

Kaspari, S., Skiles, S. M. K., Delaney, I., Dixon, D., and Painter, T. H.: Accelerated glacier melt on Snow Dome, Mount Olympus, Washington, USA, due to deposition of black carbon and mineral dust from wildfire, J. Geophys. Res., 120, 2793-2807, https://doi.org/10.1002/2014JD022676, 2015.

Kaspari, S. D., Schwikowski, M., Gysel, M., Flanner, M. G., Kang, S., Hou, S., and Mayewski, P. A.: Recent increase in black carbon concentrations from a Mt. Everest ice core spanning 1860-2000 AD, Geophys. Res. Lett., 38, 11-16, https://doi.org/10.1029/2010GL046096, 2011.

Katich, J. M., Perring, A. E., and Schwarz, J. P.: Optimized detection of particulates from liquid samples in the aerosol phase: Focus on black carbon, Aerosol Sci. Technol., 51, 543-553, https://doi.org/10.1080/02786826.2017.1280597, 2017.

Kendall, M. and Gibbons, J. D.: Rank Correlation Methods, 5th Edn., edited by: Arnold, E., Oxford University Press, London, 1990.

Khan, A. L., McMeeking, G. R., Schwarz, J. P., Xian, P., Welch, K. A., Berry Lyons, W., and McKnight, D. M.: Near-Surface Refractory Black Carbon Observations in the Atmosphere and Snow in the McMurdo Dry Valleys, Antarctica, and Potential Impacts of Foehn Winds, J. Geophys. Res.-Atmos., 123, 28772887, https://doi.org/10.1002/2017JD027696, 2018.

Khan, A. L., Klein, A. G., Katich, J. M., and Xian, P.: Local Emissions and Regional Wildfires Influence Refractory Black Carbon Observations Near Palmer Station, Antarctica, Front. Earth Sci., 7, 1-8, https://doi.org/10.3389/feart.2019.00049, 2019.

Koch, D., Bond, T. C., Streets, D., Unger, N., and van der Werf, G. R.: Global impacts of aerosols from particular source regions and sectors, J. Geophys. Res.-Atmos., 112, 1-24, https://doi.org/10.1029/2005JD007024, 2007.

Legrand, M. and Mayewski, P.: Glaciochemistry of polar ice cores: A review, Rev. Geophys., 35, 219-243, https://doi.org/10.1029/96RG03527, 1997.

Li, F., Ginoux, P., and Ramaswamy, V.: Distribution, transport, and deposition of mineral dust in the Southern Ocean and Antarctica: Contribution of major sources, J. Geophys. Res.-Atmos., 113, 115, https://doi.org/10.1029/2007JD009190, 2008.

Limpert, E., Stahel, W. A., and Abbt, M.: Log-normal Distributions across the Sciences: Keys and Clues, Bioscience, 51, 341-352, https://doi.org/10.1641/00063568(2001)051[0341:Indats]2.0.co;2, 2001.

Markle, B. R., Bertler, N. A. N., Sinclair, K. E., and Sneed, S. B.: Synoptic variability in the Ross Sea region, Antarctica, as seen from back-trajectory modeling and ice core analysis, J. Geophys. Res.-Atmos., 117, 1-17, https://doi.org/10.1029/2011JD016437, 2012.

Marquetto, L., Simões, J. C., Casassa, G., Introne, D. S., and Dos Santos, E. A.: Variações na composição isotópica de oxigênio na neve superficial ao longo de uma travessia antártica, Pesqui. em Geociencias, 42, 227-238, https://doi.org/10.22456/18079806.78122, 2015.

Marquetto, L., Kaspari, S., Simões, J. C., and Babik, E.: Refractory Black Carbon results and a method comparison between solid- state cutting and continuous melting sampling of a West Antarctic snow and firn core, Adv. Atmos. Sci., 37, 1-10, 2020.

Matsuoka, K., Skoglund, A., and Roth, G.: Quantarctica, Norwegian Polar Institute, https://doi.org/10.21334/npolar.2018.8516e961, 2018.

McConnell, J. R., Edwards, R., Kok, G. L., Flanner, M. G., Zender, C. S., Saltzman, E. S., Banta, J. R., Pasteris, D. R., Carter, M. M., and Kahl, J. D. W.: 20th-Century Industrial Black Carbon Emissions Altered Arctic Climate Forcing, Science, 317, 13811384, 2007.

Mori, T., Moteki, N., Ohata, S., Koike, M., Goto-Azuma, K., Miyazaki, Y., and Kondo, Y.: Improved technique for measuring the size distribution of black carbon particles in liquid water, Aerosol Sci. Technol., 50, 242-254, https://doi.org/10.1080/02786826.2016.1147644, 2016.

Mosley-Thompson, E., Paskievitch, J. F., Gow, A. J., and Thompson, L. G.: Late 20th Century increase in South Pole snow accumulation, J. Geophys. Res.-Atmos., 104, 3877-3886, https://doi.org/10.1029/1998JD200092, 1999.

Moteki, N. and Kondo, Y.: Dependence of laser-induced incandescence on physical properties of black carbon aerosols: Measurements and theoretical interpretation, Aerosol Sci. Technol., 44, 663-675, https://doi.org/10.1080/02786826.2010.484450, 2010.

Mudelsee, M.: Climate Time Series Analysis, 2nd Edn., Springer Netherlands, Dordrecht, 477 pp., 2010.

Neff, P. D. and Bertler, N. A. N.: Trajectory modeling of modern dust transport to the Southern Ocean and Antarctica, J. Geophys. Res.-Atmos., 120, 9303-9322, https://doi.org/10.1002/2015JD023304, 2015.

Newson, R.: Parameters behind "Nonparametric" Statistics: Kendall's tau, Somers' D and Median Differences, Stata J. Promot. Commun. Stat. Stata, 2, 45-64, https://doi.org/10.1177/1536867x0200200103, 2002.

Ni, M., Huang, J., Lu, S., Li, X., Yan, J., and Cen, K.: A review on black carbon emissions, worldwide and in China, Chemosphere, 107, 83-93, https://doi.org/10.1016/j.chemosphere.2014.02.052, 2014.

Nicolas, J. P. and Bromwich, D. H.: Climate of West Antarctica and influence of marine air intrusions, J. Clim., 24, 49-67, https://doi.org/10.1175/2010JCLI3522.1, 2011.

Osmont, D., Wendl, I. A., Schmidely, L., Sigl, M., Vega, C. P., Isaksson, E., and Schwikowski, M.: An 800-year highresolution black carbon ice core record from Lomonosovfonna, Svalbard, Atmos. Chem. Phys., 18, 12777-12795, https://doi.org/10.5194/acp-18-12777-2018, 2018.

Osmont, D., Sigl, M., Eichler, A., Jenk, T. M., and Schwikowski, M.: A Holocene black carbon ice-core record of biomass burning in the Amazon Basin from Illimani, Bolivia, Clim. Past, 15, 579592, https://doi.org/10.5194/cp-15-579-2019, 2019.

Parish, T. R. and Bromwich, D. H.: Reexamination of the Near-Surface Airflow over the Antarctic Continent and Implications on Atmospheric Circulations at High Southern Latitudes, Mon. Weather Rev., 135, 1961-1973, https://doi.org/10.1175/MWR3374.1, 2007.

Pasteris, D. R., Mcconnell, J. R., Das, S. B., Criscitiello, A. S., Evans, M. J., Maselli, O. J., Sigl, M., Layman, L., and Joaquin, S.: Seasonally resolved ice core records from West Antarctica indicate a sea ice source of sea-salt aerosol and a biomass burn- 
ing source of ammonium, J. Geophys. Res.-Atmos., 119, 36003614, https://doi.org/10.1002/2013JD021290, 2014.

Petzold, A., Ogren, J. A., Fiebig, M., Laj, P., Li, S. M., Baltensperger, U., Holzer-Popp, T., Kinne, S., Pappalardo, G., Sugimoto, N., Wehrli, C., Wiedensohler, A., and Zhang, X. Y.: Recommendations for reporting black carbon measurements, Atmos. Chem. Phys., 13, 8365-8379, https://doi.org/10.5194/acp13-8365-2013, 2013.

Ramanathan, V. and Carmichael, G.: Global and regional climate changes due to black carbon, Nat. Geosci., 1, 221-227, https://doi.org/10.1038/ngeo156, 2008.

Randerson, J. T., Chen, Y., Van Der Werf, G. R., Rogers, B. M., and Morton, D. C.: Global burned area and biomass burning emissions from small fires, J. Geophys. Res.-Biogeo, 117, G04012, https://doi.org/10.1029/2012JG002128, 2012.

Sand, M., Samset, B. H., Balkanski, Y., Bauer, S., Bellouin, N., Berntsen, T. K., Bian, H., Chin, M., DIehl, T., Easter, R., Ghan, S. J., Iversen, T., Kirkeväg, A., Lamarque, J. F., Lin, G., Liu, X., Luo, G., Myhre, G., Van Noije, T., Penner, J. E., Schulz, M., Seland, O., Skeie, R. B., Stier, P., Takemura, T., Tsigaridis, K., Yu, F., Zhang, K., and Zhang, H.: Aerosols at the poles: An AeroCom Phase II multi-model evaluation, Atmos. Chem. Phys., 17, 12197-12218, https://doi.org/10.5194/acp-17-121972017, 2017.

Schulz, M. and Mudelsee, M.: REDFIT: Estimating red-noise spectra directly from unevenly spaced paleoclimatic time series, Comput. Geosci., 28, 421-426, https://doi.org/10.1016/S00983004(01)00044-9, 2002.

Schwanck, F., Simões, J. C., Handley, M., Mayewski, P. A., Bernardo, R. T., and Aquino, F. E.: Anomalously high Arsenic concentration in a West Antarctic ice core and its relationship to copper mining in Chile, Atmos. Environ., 125, 257-264, https://doi.org/10.1016/j.atmosenv.2015.11.027, 2016a.

Schwanck, F., Simões, J. C., Handley, M., Mayewski, P. A., Bernardo, R. T., and Aquino, F. E.: Drilling, processing and first results for Mount Johns ice core in West Antarctica Ice Sheet, Brazilian J. Geol., 46, 29-40, https://doi.org/10.1590/23174889201620150035, 2016b.

Schwanck, F., Simões, J. C., Handley, M., Mayewski, P. A., Auger, J. D., Bernardo, R. T., and Aquino, F. E.: A 125-year record of climate and chemistry variability at the Pine Island Glacier ice divide, Antarctica, The Cryosphere, 11, 1537-1552, https://doi.org/10.5194/tc-11-1537-2017, 2017.

Sigl, M., Fudge, T. J., Winstrup, M., Cole-Dai, J., Ferris, D., McConnell, J. R., Taylor, K. C., Welten, K. C., Woodruff, T. E., Adolphi, F., Bisiaux, M., Brook, E. J., Buizert, C., Caffee, M. W., Dunbar, N. W., Edwards, R., Geng, L., Iverson, N., Koffman, B., Layman, L., Maselli, O. J., McGwire, K., Muscheler, R., Nishiizumi, K., Pasteris, D. R., Rhodes, R. H., and Sowers, T. A.: The WAIS Divide deep ice core WD2014 chronology Part 2: Annual-layer counting (0-31 ka BP), Clim. Past, 12, 769786, https://doi.org/10.5194/cp-12-769-2016, 2016.

Sinclair, K. E., Bertler, N. A. N., and Trompetter, W. J.: Synoptic controls on precipitation pathways and snow delivery to high-accumulation ice core sites in the Ross Sea region, Antarctica, J. Geophys. Res.-Atmos., 115, 1-11, https://doi.org/10.1029/2010JD014383, 2010.

Soto-García, L. L., Andreae, M. O., Andreae, T. W., Artaxo, P., Maenhaut, W., Kirchstetter, T., Novakov, T., Chow, J. C., and
Mayol-Bracero, O. L.: Evaluation of the carbon content of aerosols from the burning of biomass in the Brazilian Amazon using thermal, optical and thermal-optical analysis methods, Atmos. Chem. Phys., 11, 4425-4444, https://doi.org/10.5194/acp11-4425-2011, 2011.

Stein, A. F., Draxler, R. R., Rolph, G. D., Stunder, B. J. B., Cohen, M. D., and Ngan, F.: NOAA's HYSPLIT Atmospheric Transport and Dispersion Modeling System, B. Am. Meteorol. Soc., 96, 2059-2077, https://doi.org/10.1175/BAMS-D-14$00110.1,2015$.

Stohl, A. and Sodemann, H.: Characteristics of atmospheric transport into the Antarctic troposphere, J. Geophys. Res.-Atmos., 115, 1-16, https://doi.org/10.1029/2009JD012536, 2010.

Strahan, S. E., Oman, L. D., Douglass, A. R., and Coy, L.: Modulation of Antarctic vortex composition by the quasibiennial oscillation, Geophys. Res. Lett., 42, 4216-4223, https://doi.org/10.1002/2015GL063759, 2015.

Tao, G., Yamada, R., Fujikawa, Y., Kudo, A., Zheng, J., Fisher, D. A., and Koerner, R. M.: Determination of trace amounts of heavy metals in arctic ice core samples using inductively coupled plasma mass spectrometry, Talanta, 55, 765-772, https://doi.org/10.1016/S0039-9140(01)00509-4, 2001.

Thoen, I. U., Simões, J. C., Lindau, F. G. L., and Sneed, S. B.: Ionic content in an ice core from the West Antarctic Ice Sheet: 1882-2008 A.D., Brazilian J. Geol., 48, 853-865, https://doi.org/10.1590/2317-4889201820180037, 2018.

Torres, A., Bond, T. C., Lehmann, C. M. B., Subramanian, R., and Hadley, O. L.: Measuring organic carbon and black carbon in rainwater: Evaluation of methods, Aerosol Sci. Technol., 48, 239-250, https://doi.org/10.1080/02786826.2013.868596, 2014.

Turner, J., Phillips, T., Hosking, J. S., Marshall, G. J., and Orr, A.: The Amundsen Sea low, Int. J. Climatol., 33, 1818-1829, https://doi.org/10.1002/joc.3558, 2013.

Wang, M., Xu, B., Zhao, H., Cao, J., Joswiak, D., Wu, G., and Lin, S.: The Influence of Dust on Quantitative Measurements of Black Carbon in Ice and Snow when Using a Thermal Optical Method, Aerosol Sci. Technol., 46, 60-69, https://doi.org/10.1080/02786826.2011.605815, 2012.

Warren, S. G. and Clarke, A. D.: Soot in the atmosphere and snow surface of antarctica, J. Geophys. Res., 95, 1811-1816, 1990.

van der Werf, G. R., Randerson, J. T., Giglio, L., van Leeuwen, T. T., Chen, Y., Rogers, B. M., Mu, M., van Marle, M. J. E., Morton, D. C., Collatz, G. J., Yokelson, R. J., and Kasibhatla, P. S.: Global fire emissions estimates during 1997-2016, Earth Syst. Sci. Data, 9, 697-720, https://doi.org/10.5194/essd-9-697-2017, 2017.

Winstrup, M., Vallelonga, P., Kjær, H. A., Fudge, T. J., Lee, J. E., Riis, M. H., Edwards, R., Bertler, N. A. N., Blunier, T., Brook, E. J., Buizert, C., Ciobanu, G., Conway, H., Dahl-Jensen, D., Ellis, A., Emanuelsson, B. D., Hindmarsh, R. C. A., Keller, E. D., Kurbatov, A. V., Mayewski, P. A., Neff, P. D., Pyne, R. L., Simonsen, M. F., Svensson, A., Tuohy, A., Waddington, E. D., and Wheatley, S.: A 2700-year annual timescale and accumulation history for an ice core from Roosevelt Island, West Antarctica, Clim. Past, 15, 751-779, https://doi.org/10.5194/cp-15-7512019, 2019.

Witherow, R. A. and Lyons, W. B.: Mercury deposition in a polar desert ecosystem, Environ. Sci. Technol., 42, 4710-4716, https://doi.org/10.1021/es800022g, 2008. 